\title{
The Cognitive Pattern of Selecting the Most Effective Carbon Disclosure Strategy Based on Stakeholder Social Pressures: Rough Collection Analytical
}

\author{
Sahar Amani Babadi \\ PhD Student in Accounting, Ahvaz Branch, Islamic Azad University, Ahvaz, \\ Iran(s.amanibabadi@gmail.com) \\ Alah karam Salehi* \\ Assistant Professor, Department of Accounting, Masjed Soleiman Branch, \\ Islamic Azad University, Masjed Soleiman, Iran((Corresponding author), \\ A.K.salehi@iaumis.ac.ir \\ Mohammad Khodamoradi \\ Assistant Professor, Department of Mathematics, Izeh Branch, Islamic Azad \\ University, Izeh, Iran (Mohammad_moradi57@yahoo.com) \\ Alireza J orjorzadeh \\ Assistant Professor, Department of Economics, Ahvaz Branch, Islamic Azad \\ University, Ahvaz, Iran(Arjorjor@iauahvaz.ac.ir)
}

\begin{abstract}
:
With the expansion of social interactions and the development of regulatory tools, stakeholders today are seen as an important and important part in strengthening corporate social responsibility practices. Social pressures, in order to increase the level of sustainable functions, affect the environmental performance of companies and cause companies to provide information to persuade social expectations in a competitive environment by relying on behavioral and specialized approaches. One of these approaches is carbon exposure strategies based on the social pressures of stakeholders. In this study, its purpose Provide a cognitive model for selecting the effectiveness carbon exposure strategy based on stakeholder social pressures at the capital market level, Efforts were made to use the participation of two groups of people in the target community at the university level and at the capital market level and based on the nature of research in the qualitative section, From two Metasynthesis and Delphi and in the quantitative research section, use the Raff's analyzes. This research was conducted in the period 2019-2020 year. The results in the qualitative section, by examining 29 screened studies, confirmed the 15 social pressure propositions of stakeholders as analysis criteria and 3 strategic components of carbon disclosure as Ruff analysis rules.
\end{abstract}


After Delphi analysis to determine the theoretical adequacy, the number of propositions they were reduced to 14 social stress statements and 3 components of carbon exposure strategies were approved .Then, at the level of analysis of Raff collection, which was based on matrix analysis and with the participation of managers in different layers of capital market companies, the results showed that out of 14 propositions, three propositions tend to be socially accepted M5; The tendency to change the social norms of the M8 and the disclosure of the normative information of the M2 becomes the most important statement in the social pressure for the use of carbon disclosure strategies by companies. It was also found that the strategy of voluntary disclosure of carbon, based on the social pressures of stakeholders, is the most important strategy in disclosing carbon functions by companies that can help develop interactions in a competitive market.

Key Words: Carbon Disclosure Strategy, Social Pressures Stakeholders, Rough Analyzing

\section{Copyrights (c) (1)(2)}

This license only allowing others to download your works and share them with others as long as they credit you, but they can't change them in any way or use them commercial. 


\section{مقاله يخووهشى}

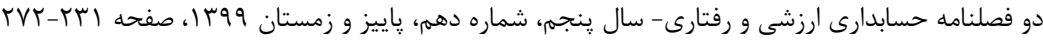

\section{الكوى شناختى انتخاب تاثير كذارترين راهبر د افشاى كربن براساس}

\section{فشار هاى اجتماعى ذينفعان: رويكردهاى تحليلى مجموعه راف}

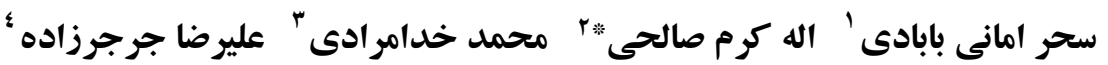

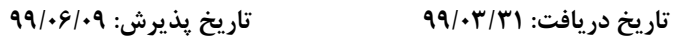

جكيده

با گَسترده شدن تعاملات اجتماعى و توسعه ابزارهاى نظارتى، امروزه ذينفعان به عنوان يك

بخش مهم و با اهميت در تقويت عملكردهاى توام با مسئوليت اجتماعى شركتها محسوب

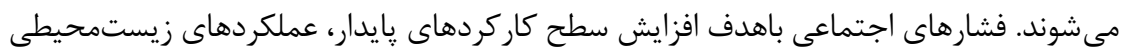
شركتها را تحت تاثير قرار مىدهد و باعث مى رويكردهاى رفتارى و تخصصى، اقدام به ارائه اطلاعات براى اقناع انتظارات اجتماعى بنمايند. يكى

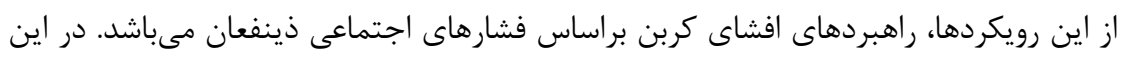
يروهش كه هدف آن ارائه يك الكوى شناختى جهت انتخاب تاثير گذارترين راهبردِ افشاى كربن براساس فشارهاى اجتماعى ذينفعان در سطح بازار سرمايه، تلاش شد از مشاركت دو گروه از افراد جامعه هدف در سطح دانشگاه و در سطح بازار سرمايه استفاده شود و برمبناى ماهيت يزوهش براس در بخش كيفى، از دو تحليل فراتركيب و دلفى و در بخش كمى از مجموعٍ تحليلهاى راف

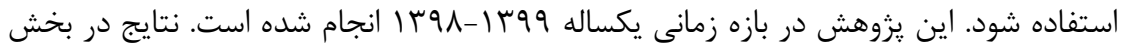
كيفى با بررسى وج يزوهش غربال شده، تعداد ها گزاره فشار اجتماعى ذينفعان به عنوان

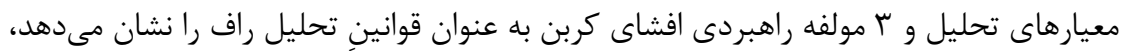

$$
\begin{array}{r}
\text { 'دانشجوى دكترى حسابدارى، واحد اهواز، دانشعاه آزاد اسلامى، اهواز، ايران } \\
\text { (s.amanibabadi@gmail.com) }
\end{array}
$$

ז'استاديار، گروه حسابدارى، واحد مسجدسليمان، دانشگاه آزاد اسلامى، مسجدسليمان، ايران(نويسنده A.K.salehi@iaumis.ac.ir ، مسئول، وحوه "استاديار، گروه رياضى، واحد ايذه، دانشعاه آزاد اسلامى، ايذه، ايران

(Mohammad_moradi57@yahoo.com) (Arjorjor@iauahvaz.ac.ir)(استاديار، گروه اقتصاد، واحد اهواز، دانشخاه آزاد اسلامى، اهواز، ايران، 


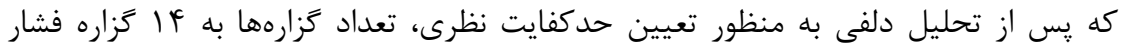

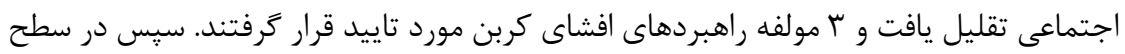
تحليل مجموعه راف كه براساس تحليلهاى ماتريسى و با مشاركت مديران در لايههاى مختلف

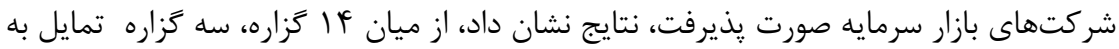

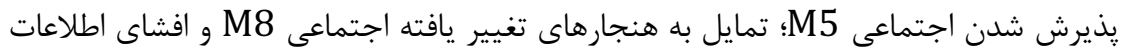

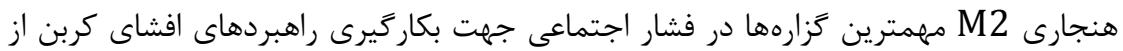

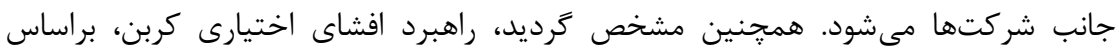

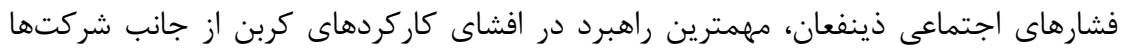
مىباشد كه مىتواند به توسعه تعاملات در سطح بازار رقابتى كمكى نمايد.

وازَّان كليدى: راهبردهاى افشاى كربن؛ فشارهاى اجتماعى ذينفعان؛ تحليل مجموعه راف 


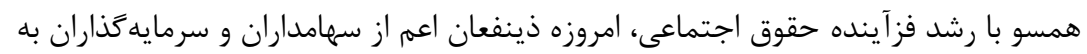

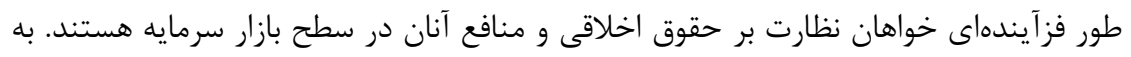

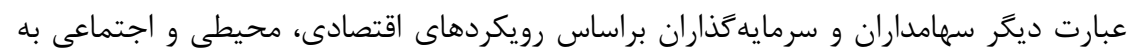

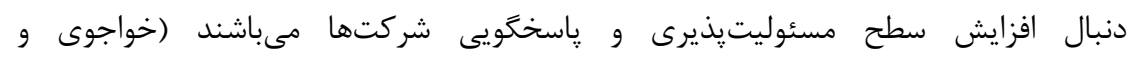

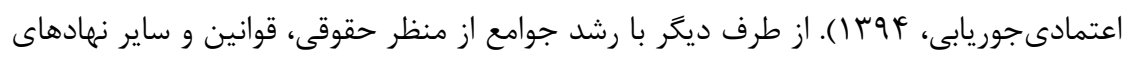

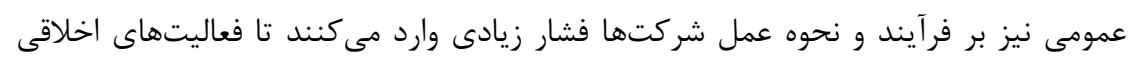

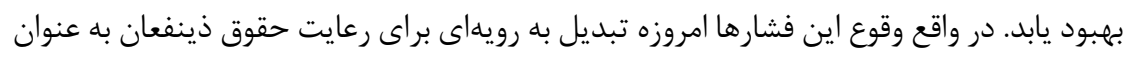

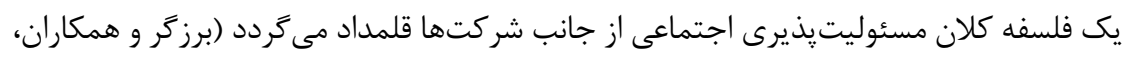

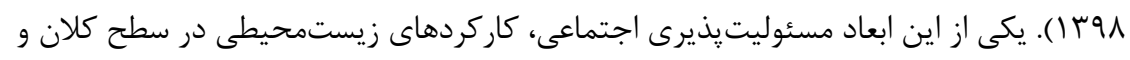

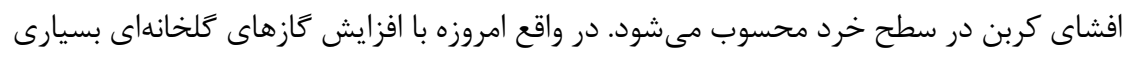

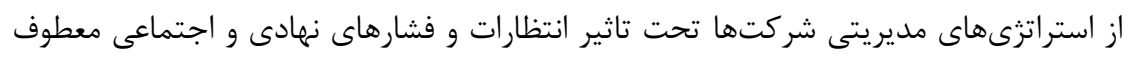

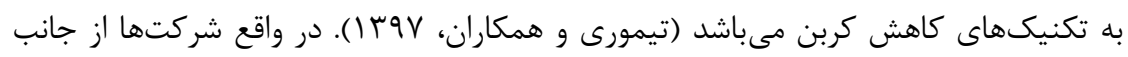

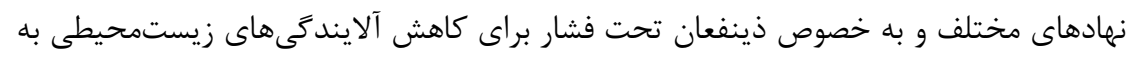

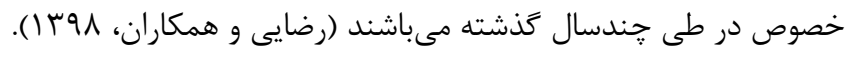

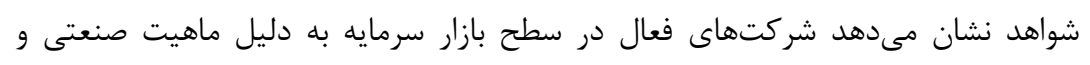

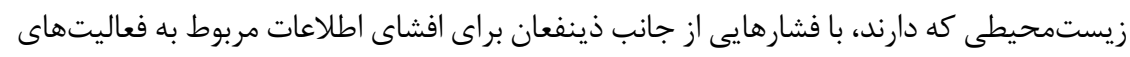

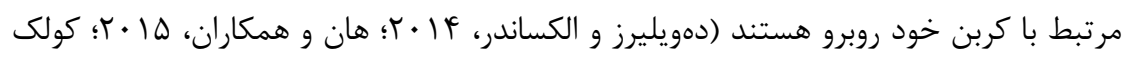

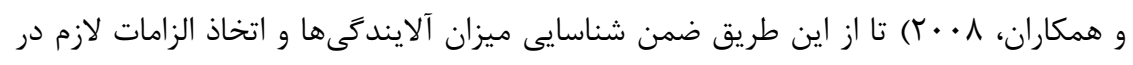

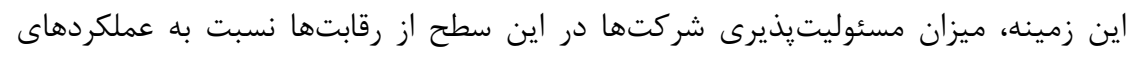

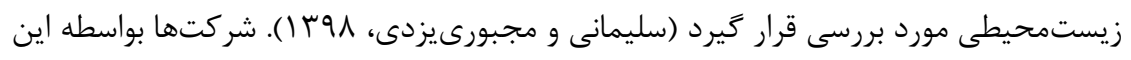

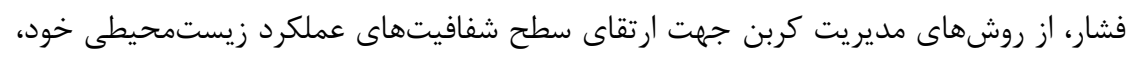

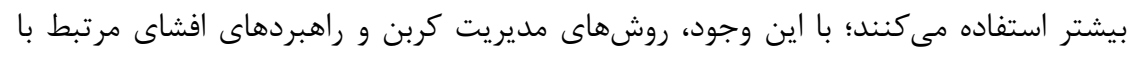

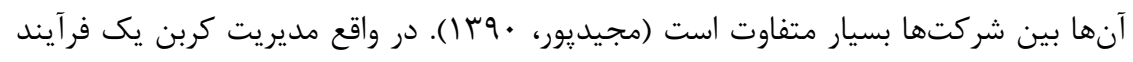

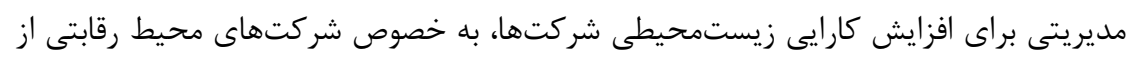

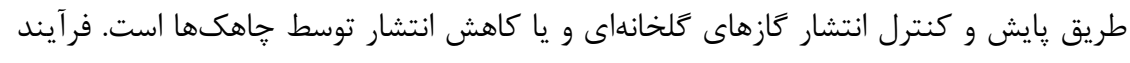

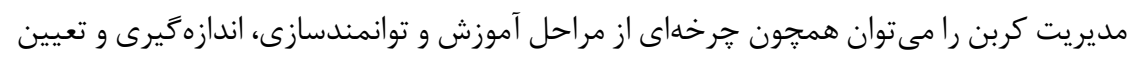

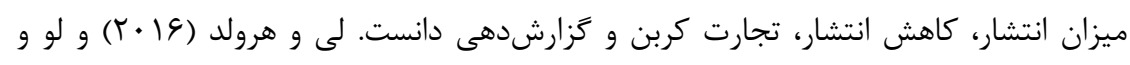

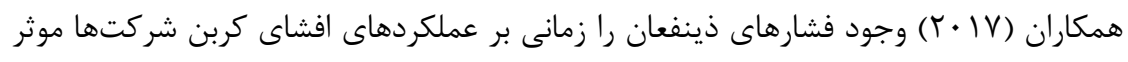


مى دانند، كه ضمن دار ابودن الزامهاى نهادى، همجنين از منطق هاى نهادى ' براى تماى توجيح دلايل

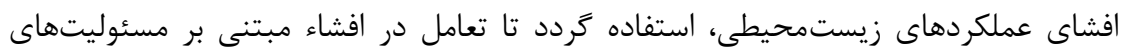

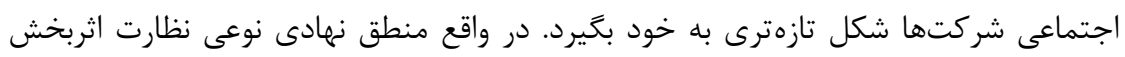

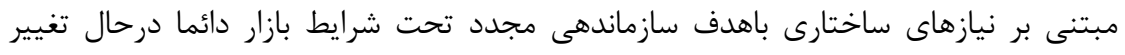

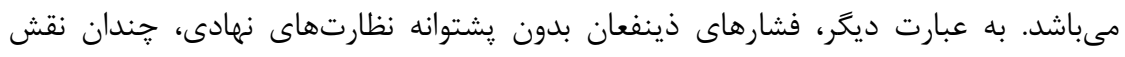

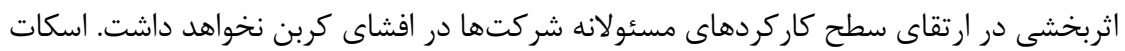

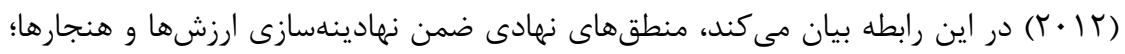

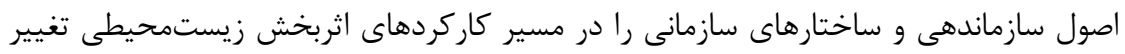

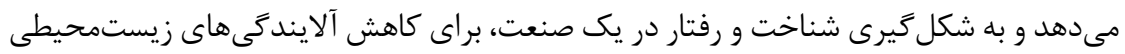

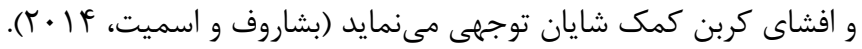

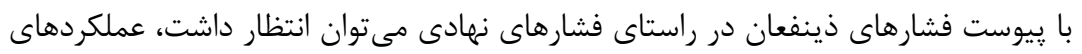

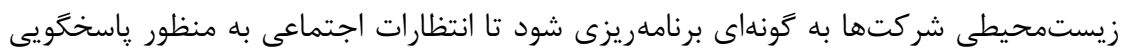

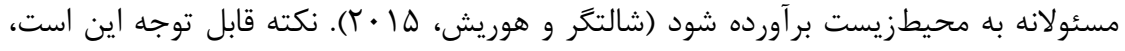

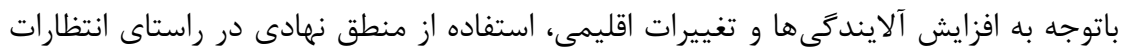

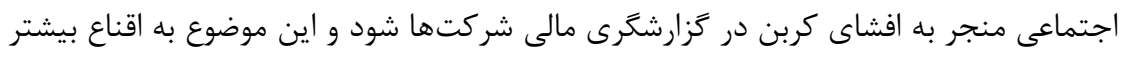

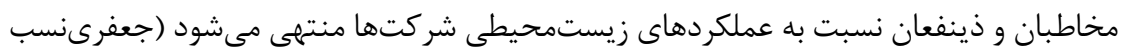

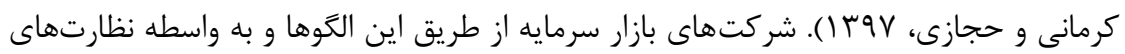

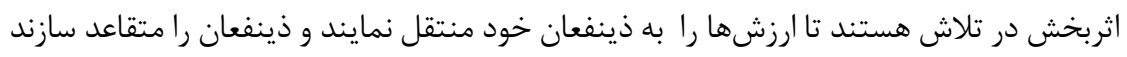

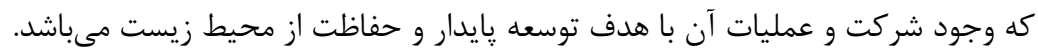

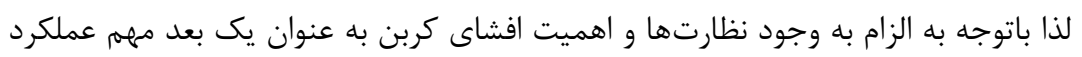

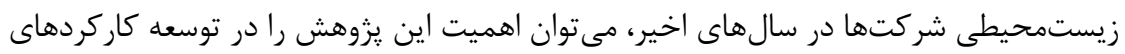

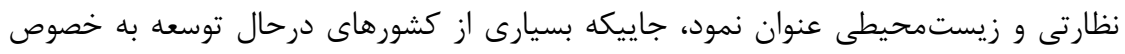

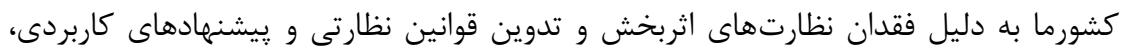

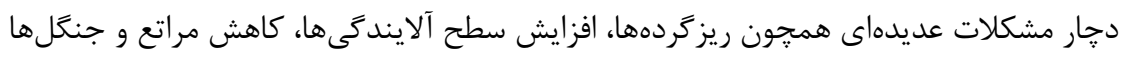

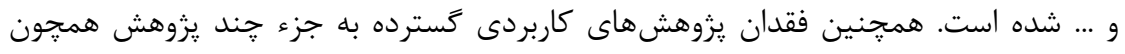

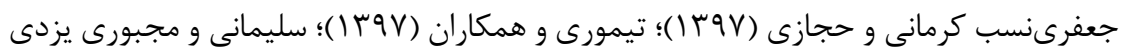

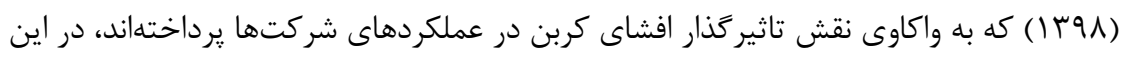

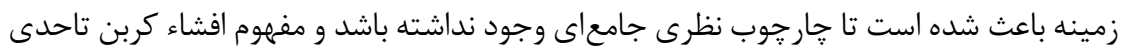

${ }^{1}$ Institutional logics 
حه از نظر تئورى و حه از كاربردى توسعه نيافته باشد. لذا با بررسى ابعاد راهبردى افشاء كربن

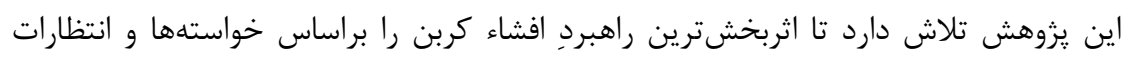

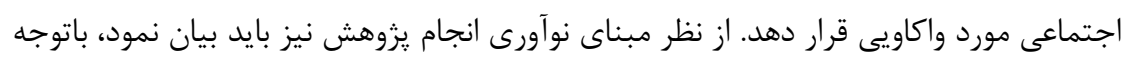

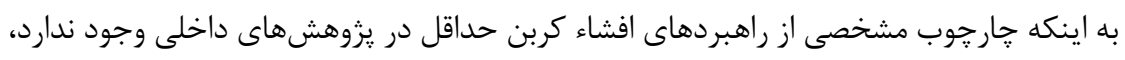

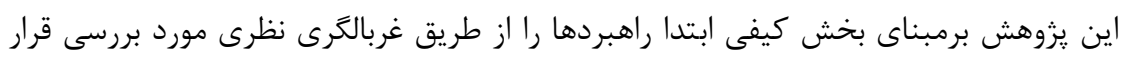

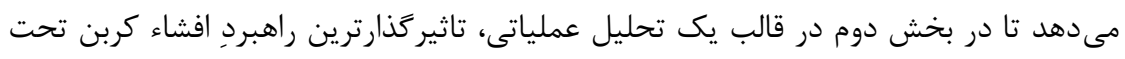

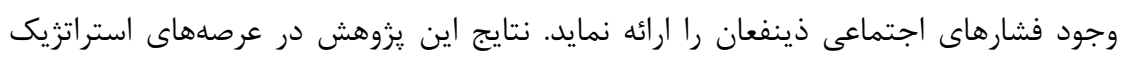

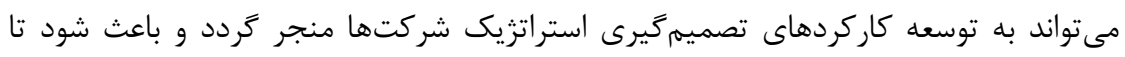

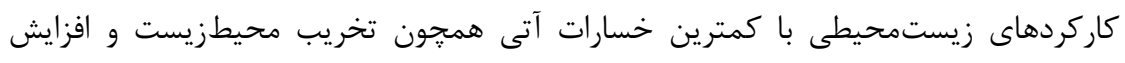

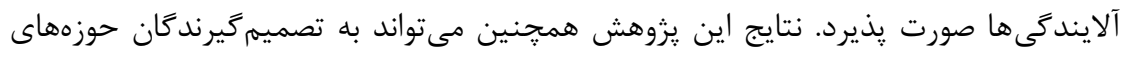

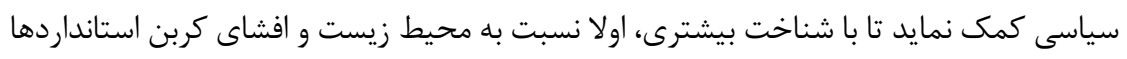

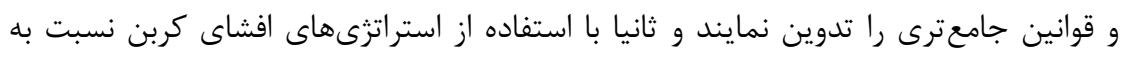

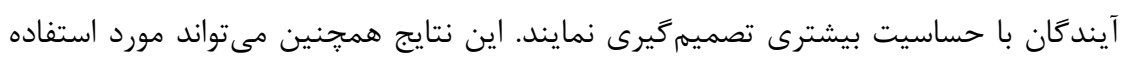
تحليل

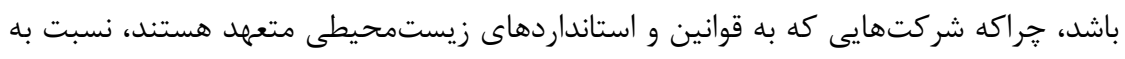

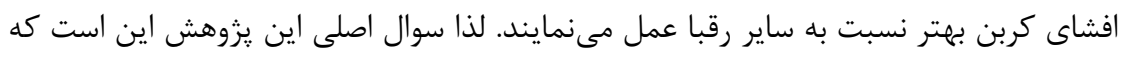

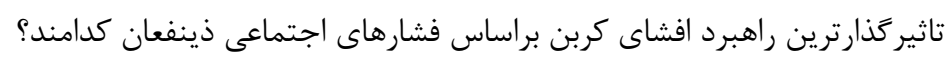

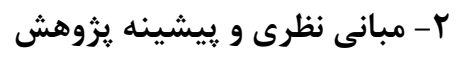

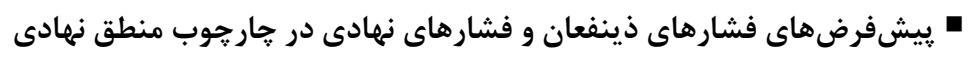

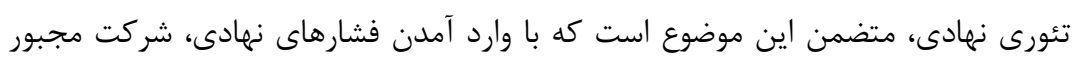

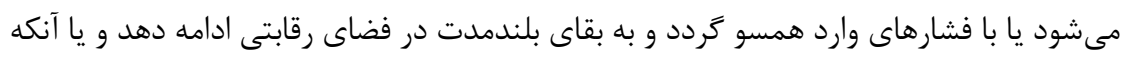

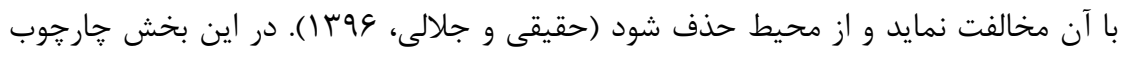

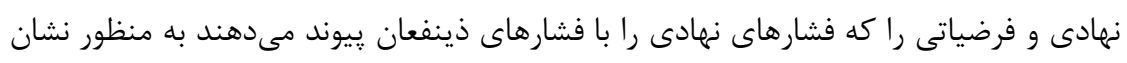

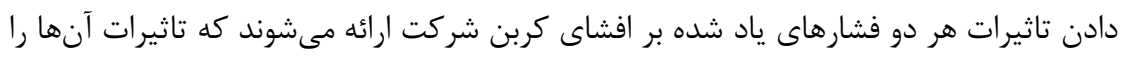

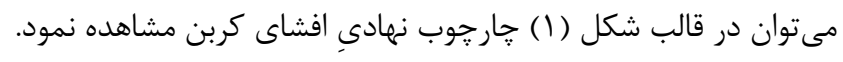


دو فصلنامه حسابدارى ارزشى و رفتارى، سال ينجم، شماره دهم، پِاييز و زمستان وجها

דז

شكل (1) يِشفرض هاى هماهنَ فشارهاى ذينفعان با فشارهاى نهادى در جار „جوب منطق

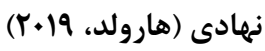

خرد (سطح شركت)

تاثيركذاري فشار نهادي بر عملكرد شركت

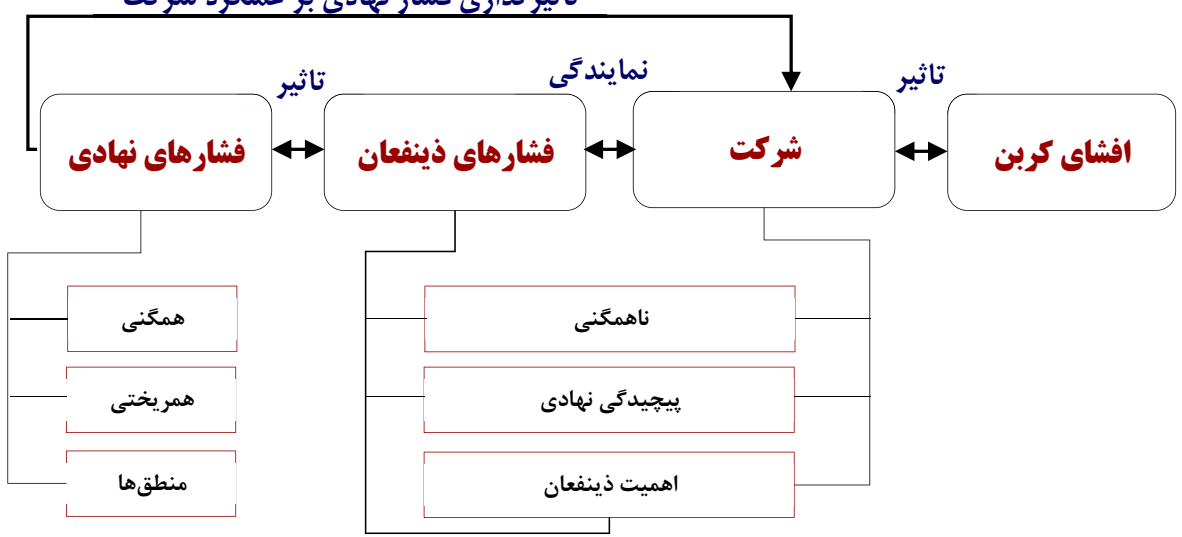

منطق نهادى به عنوان فرآيندى مبتنى بر تغييرات ساختارى با هدف سازماندهى مجدد، براى

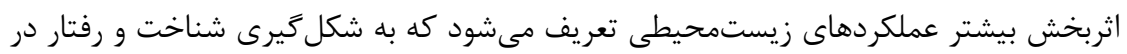

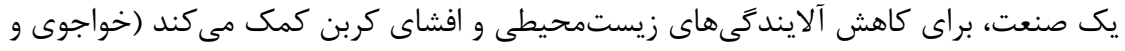

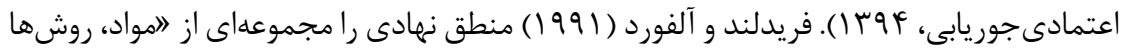

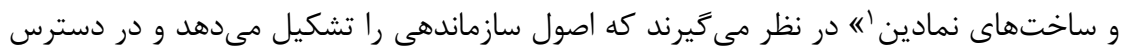

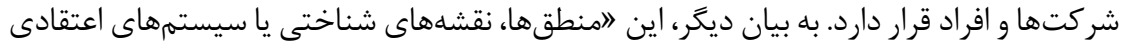
مشاركت كنند

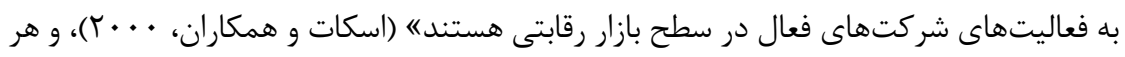

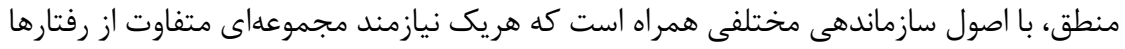

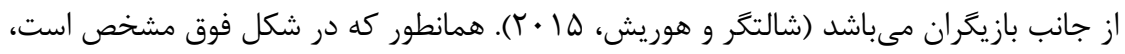

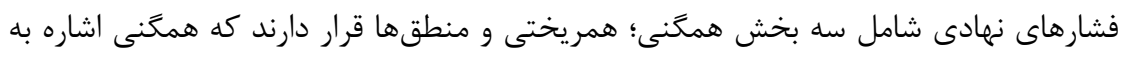

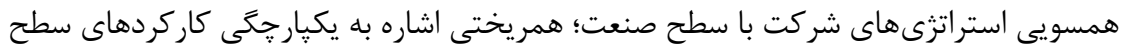

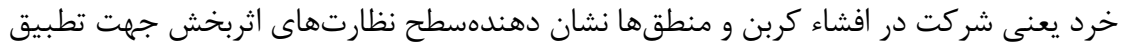

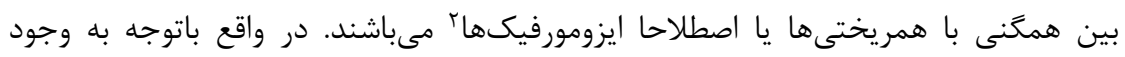

${ }^{1}$ Symbolic Constructions

${ }^{2}$ Isomorphi 
فشارهاى نهادى، بروز اين سه معيار يعنى همخنى؛ همريختى و منطقهاى مى تواند به توسعه

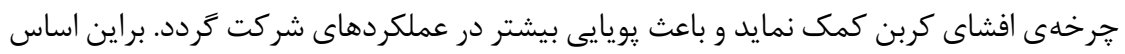

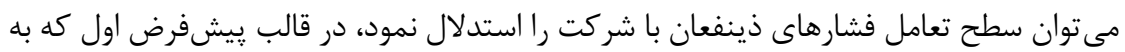

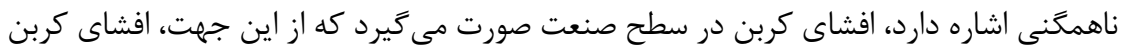

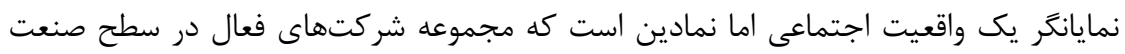
خاص، در قالب شاخصهايى همجون آلايندَّى، زيستمحيطى، سبز و ... افشا مينمايند (مير و

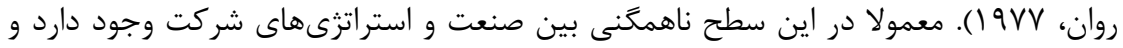

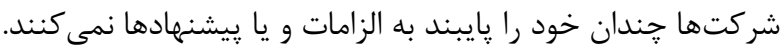

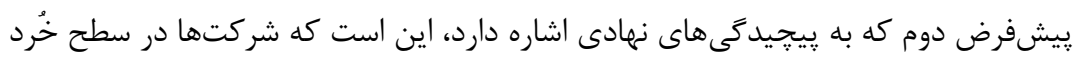
با فشارهاى نهادى همجون نهادهاى حمايتى از مصرفكنندكان، نهادهاى نظارتى و قضايى،

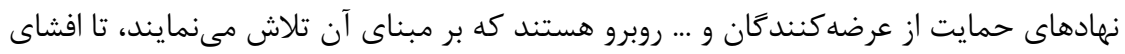
كربن هرجند به صورت پِيحِيده اما در سطح تفكيك شدهترى توسط شركتهان

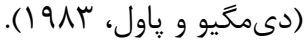

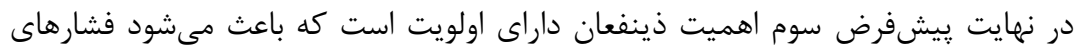

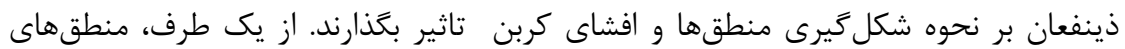
نهادى شامل مجموعههاى مختلفى از توجيهات فرهنكى هستند كه براساس آنها ذينفعان تصميم

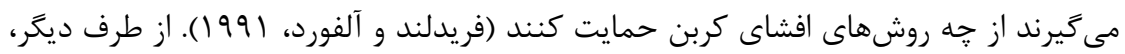

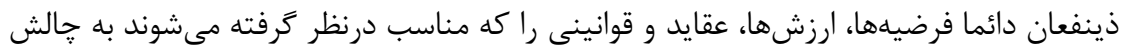
مى كشند، و بدين طريق نقشى محورى در شكل كيرى منطقهاى نهادى و نتايج و رفتار شركت

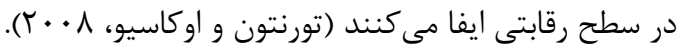

n نقش ذينفعاندر توسعه افشاى كربن

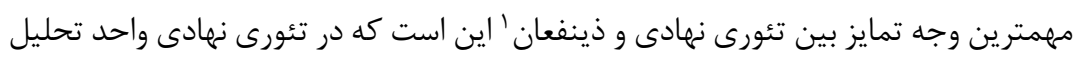

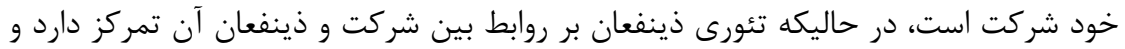

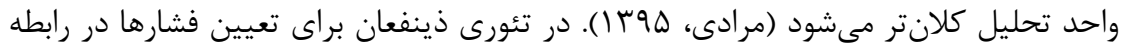

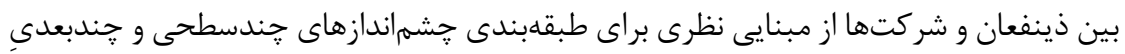

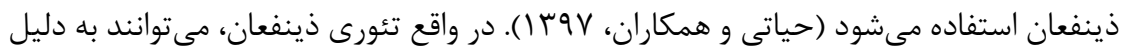

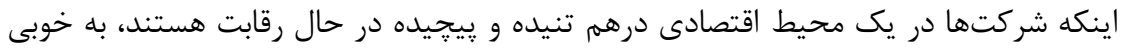

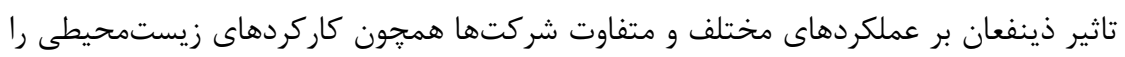

${ }^{1}$ Stakeholder 


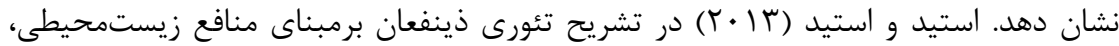

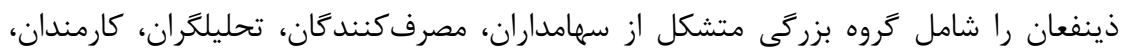

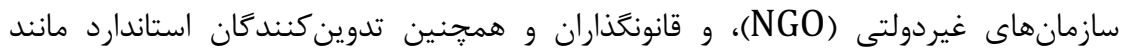

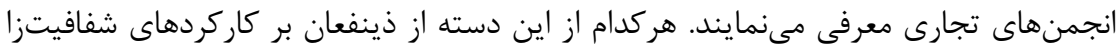

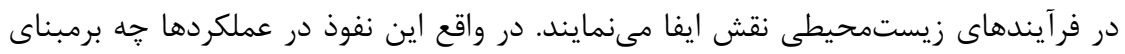

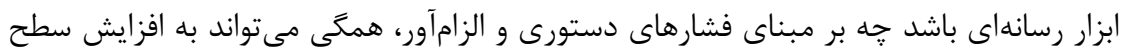

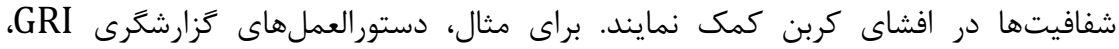

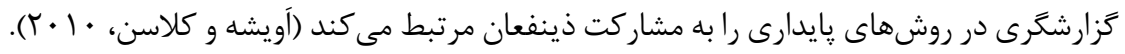

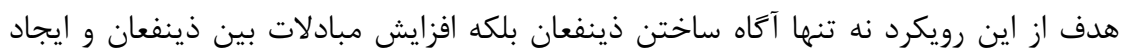

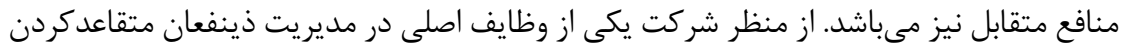

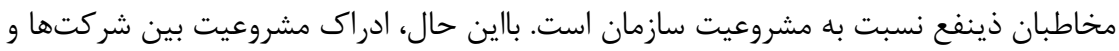

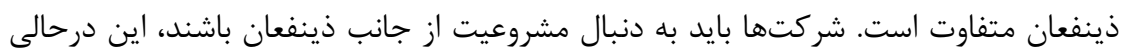

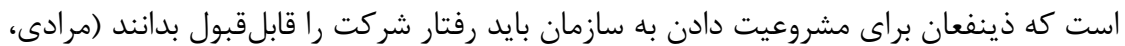

بايد توجه داشت اغلب مديران تحت تاثير فاكتورهاى متعددى از جمله ارزشها، اصول، و

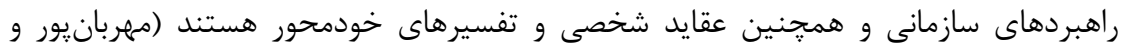

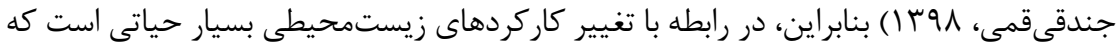

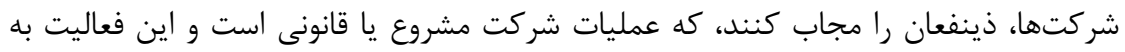

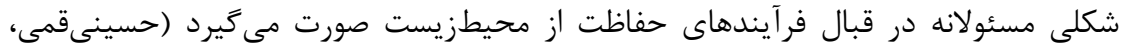

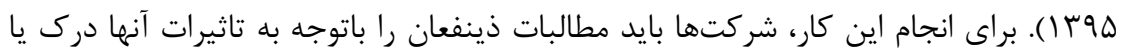

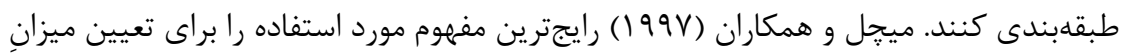

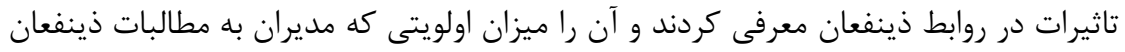

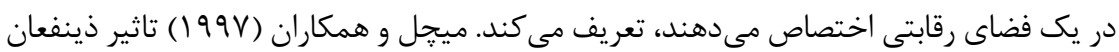
را در قالب شكل ه نشان داده است.

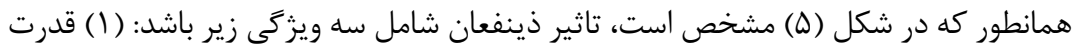

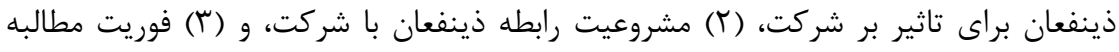
ذينفعان در مورد شركت. 
شكل (ه) عوامل موثر بر تاثير ذينفعان در بازار (ميجِل و همكاران، 199V)

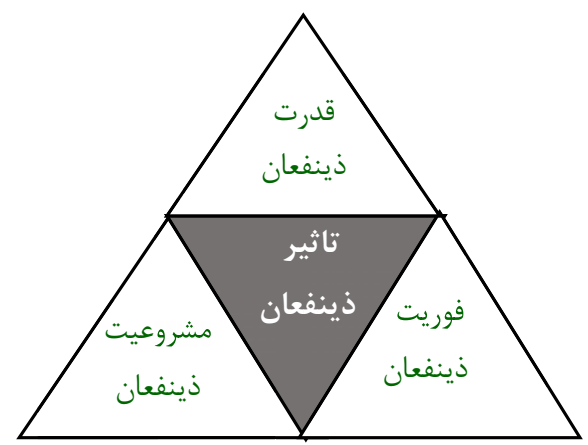

قدرت ذينفعان' به تاثير كسانى اشاره دارد كه منابع حياتى شركت را كنترل مى كنند و بدين

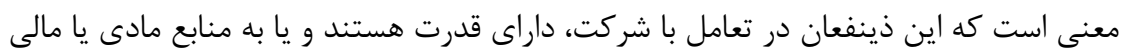

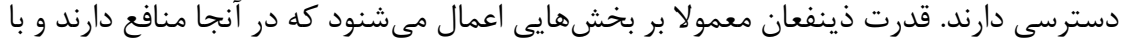

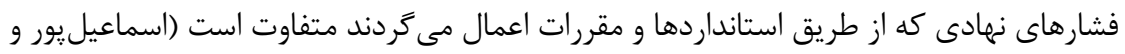

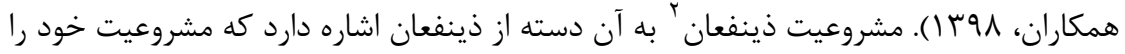

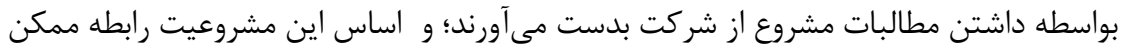

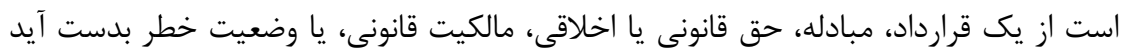

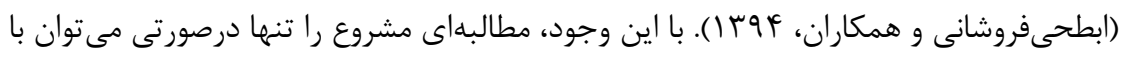
اهميت دانست كه ذينفع بتواند خواسته خود را تحميل كند، يا اينكه اين مطالبه فورى تلقى

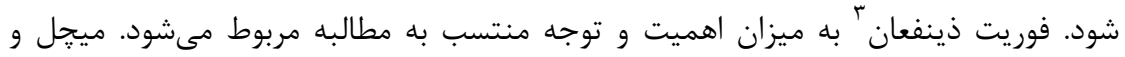

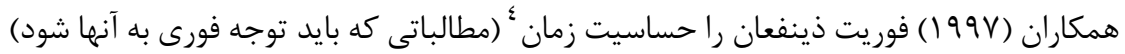

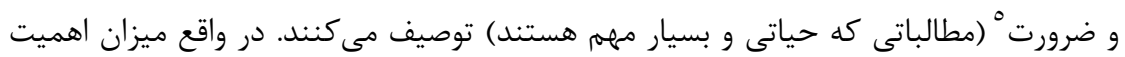

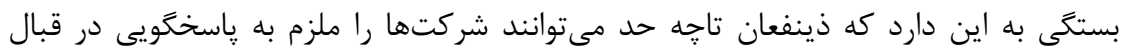

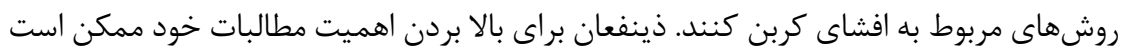

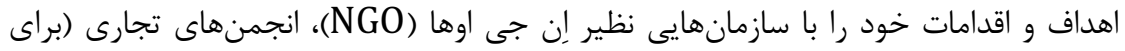

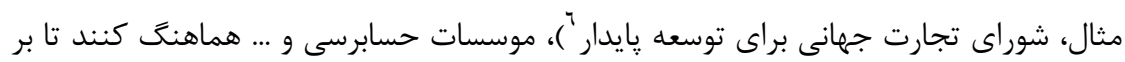

${ }^{1}$ Stakeholder Power

${ }^{2}$ Stakeholder Legitimacy

${ }^{3}$ Stakeholder Urgency

${ }^{4}$ Sensitivity of Time

${ }^{5}$ Necessity

${ }^{6}$ World Business Council for Sustainable Development 
مبناى آن، مطالبات آنها از قابليت فوريت بيشترى برخوردار باشد. بهعبارت ديكر، جنين

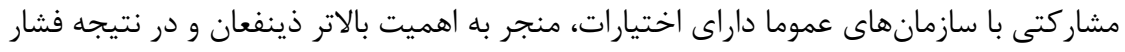
بيشتر بر شركتها خواهد شود. از آنجاييكه يكى از مطالبات در بات باب افشاى الفاى عملكردهاى

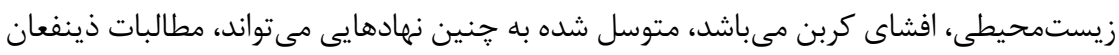

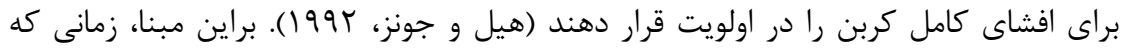

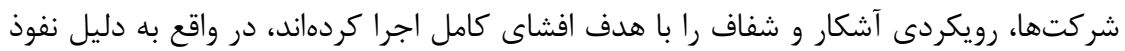
ذينفعان در ساير نهادهاى نظارتى بر عملكرد شركت بوده است كه باعث شده اهميت انتطارات

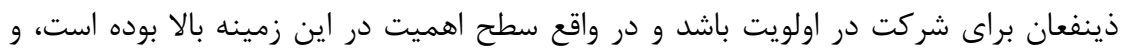

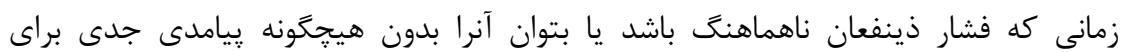

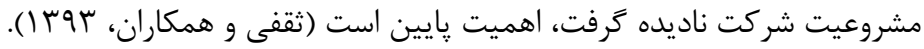

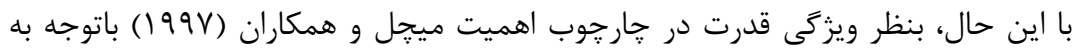

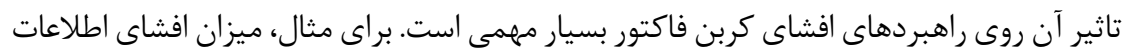

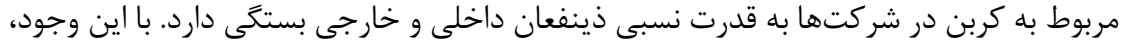

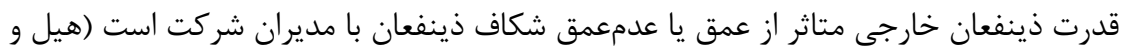

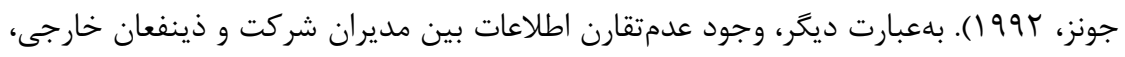
نشاندهنده سطح قدرت تصميم گيرى پايين اين دسته از ذينفعان مىباشد. بهطوريكه مديران

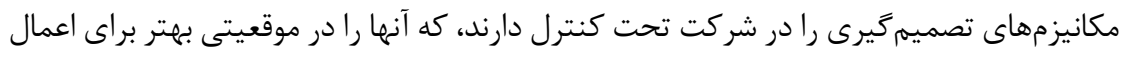

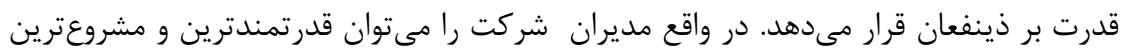

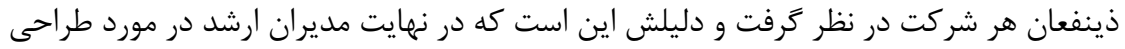

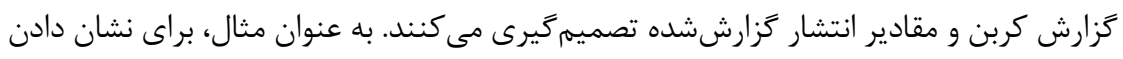

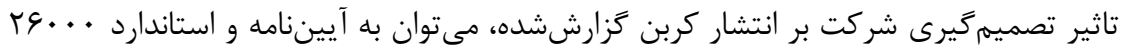

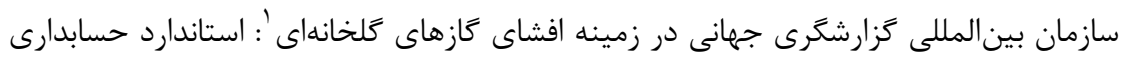

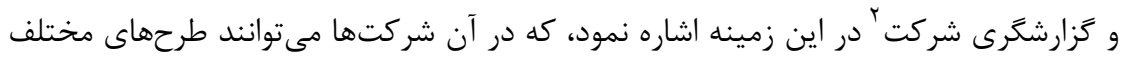

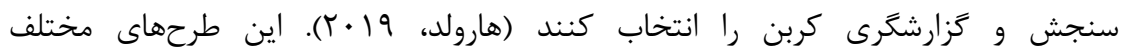

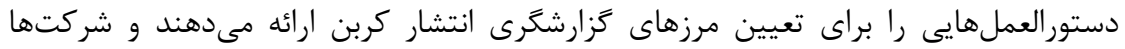

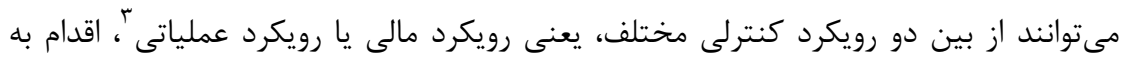

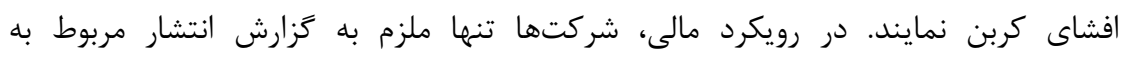

1 The Greenhouse Gas Protocol

${ }^{2}$ A Corporate Accounting and Reporting Standard

${ }^{3}$ Operational Approach 
سرمايه كذارىهايى هستند كه بيش از • •ه/ درصد در آن سهم داشته باشند (همان منبع). به

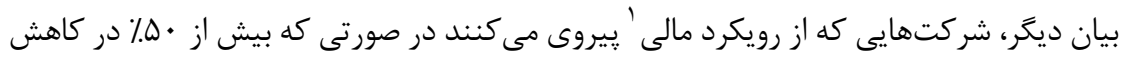

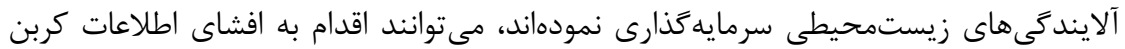
نمايند، در حاليكه در رويكرد عملياتى، سنجش و افشاى كربن در ززارشكرى مالى تنها، محدود

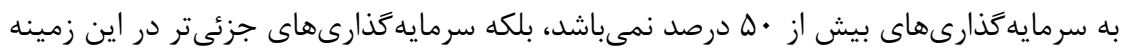

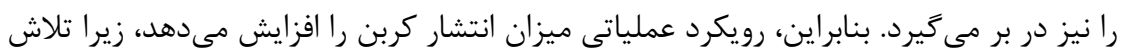
مى كند سطح شفافيت بيشترى را در اين زمينه افشاء نمايد. تئورى راف

تئورى مجموعه راف يك روش رياضى جديد براى دانش ناقص يعنى براى ابهام يا دقت بإيين

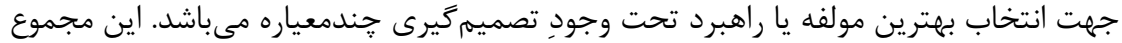

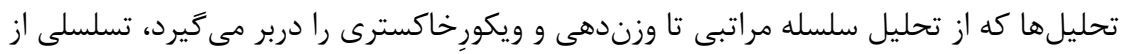

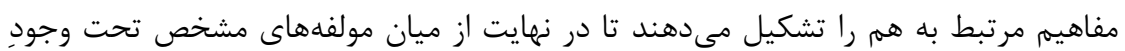

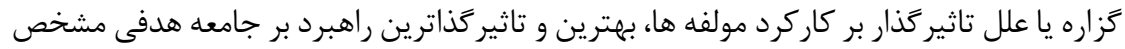

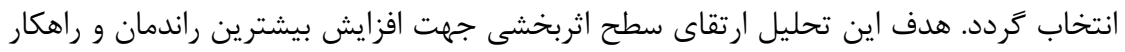

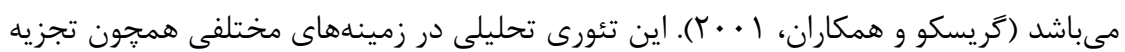
و تحليل تصميم گيرى، سيستمهاى پشتيبان تصميم، حل مسئله، سيستمهاى فناورى اطلاعات

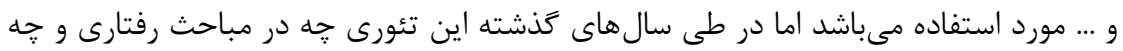

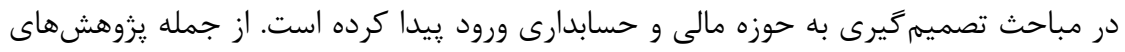

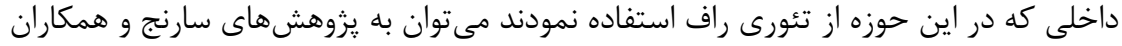

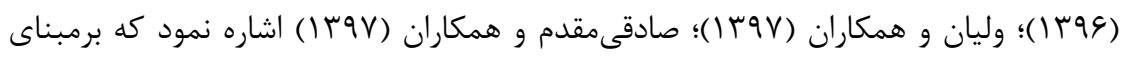

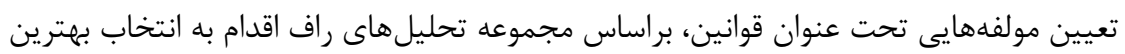

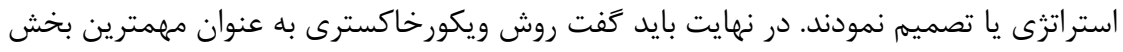

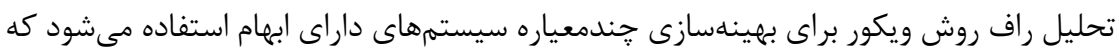

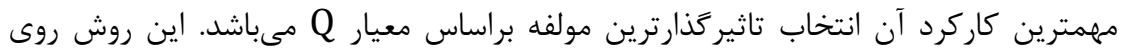

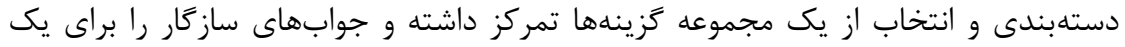

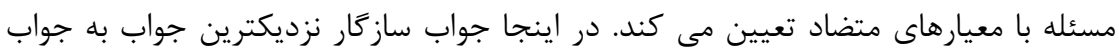

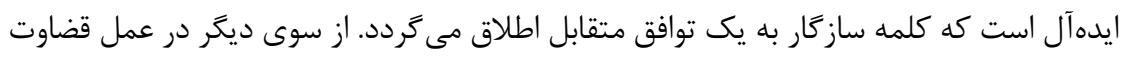

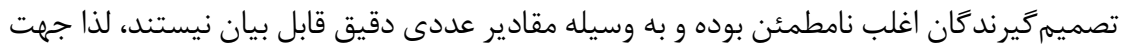

\footnotetext{
${ }^{1}$ Financial Approach
} 
مواجها با اين ييجيدگى ها، استفاده از رويكردهاى جديد بين رشتهاى نظير تئورى خاكسترى كه

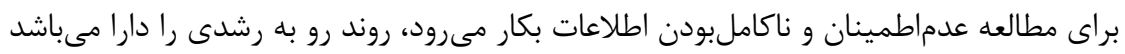

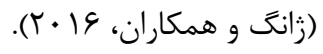

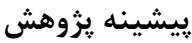

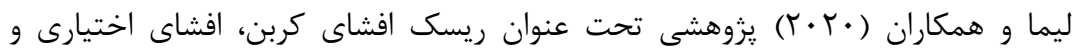

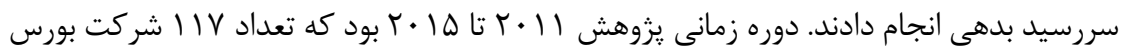

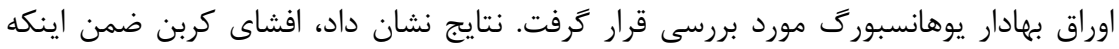

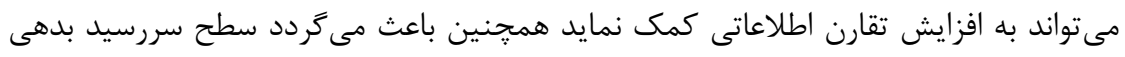

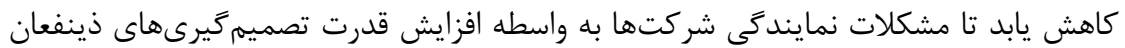
تقويت تردد. هارولد (Y. (Y) يزوهشى تحت عنوان تعامل بين فشارهاى نهادى و ذينفعان: پِيشبرد

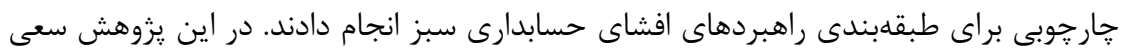

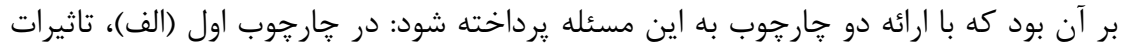

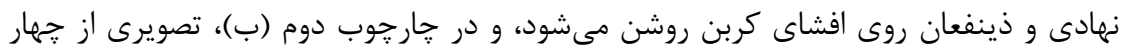

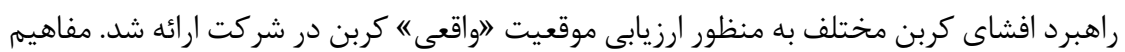

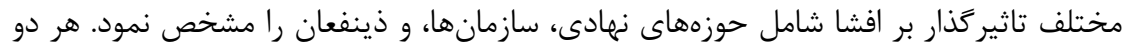

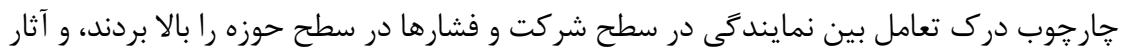

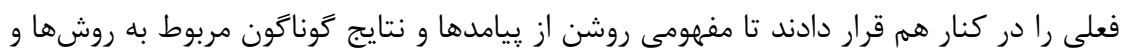
راهبردهاى افشاى كربن ارائه دهند.

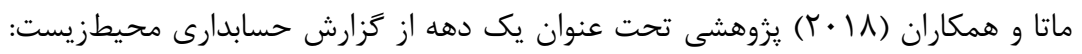

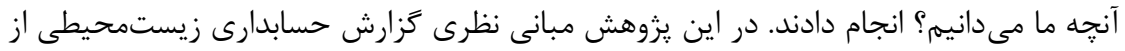

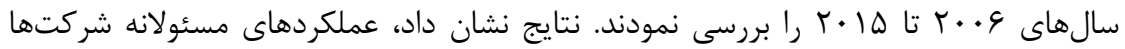

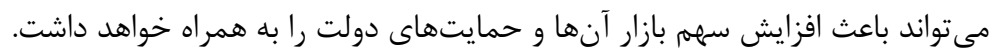

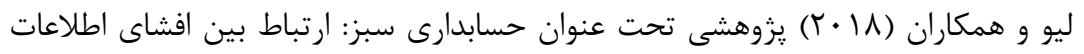

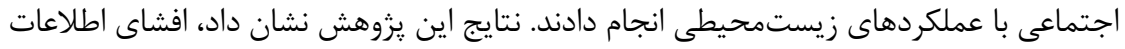

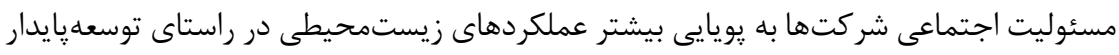
حسابدارى زيستمحيطى منجر خواهد شد.

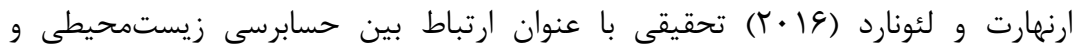

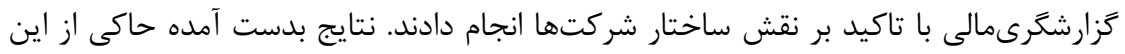


مىباشد كه ساختار شركتها بر رابطه بين حسابرسى زيستمحيطى و كيفيت كزارشكرىمالى شركتها تأثير دارد.

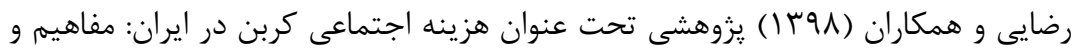

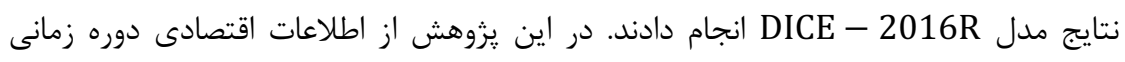

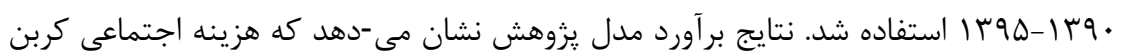

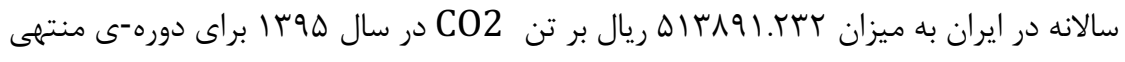

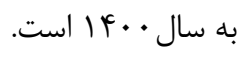

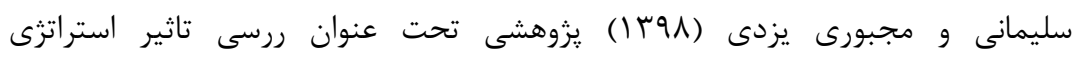

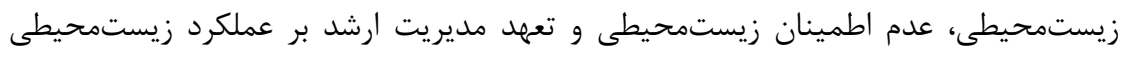

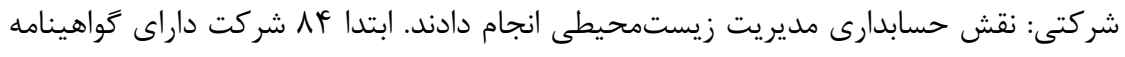

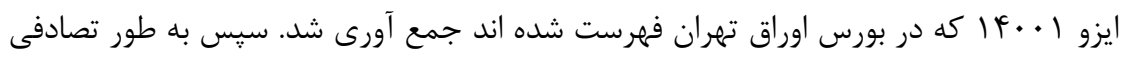

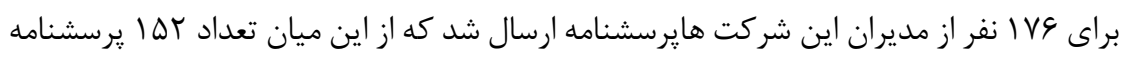

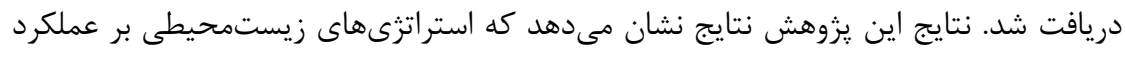
زيستمحيطى شركتها تاثير مثبت معنادارى دارند.

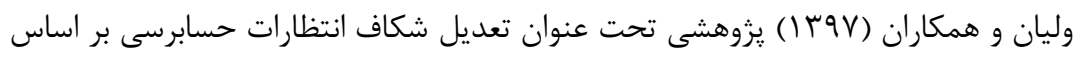

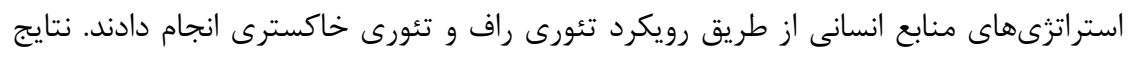

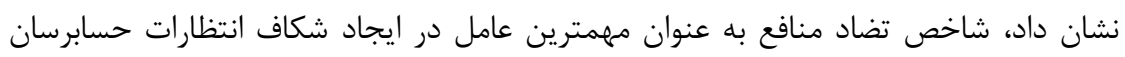

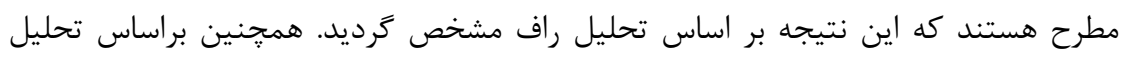

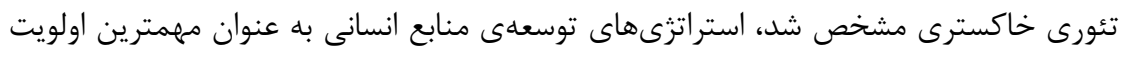

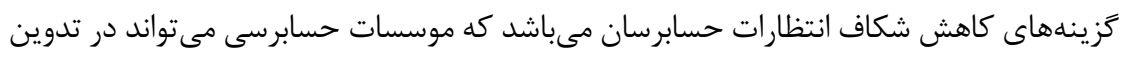

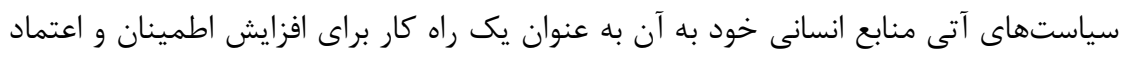

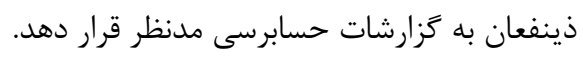

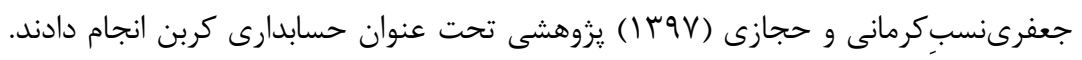

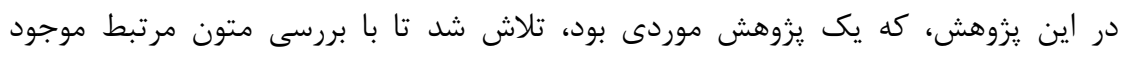

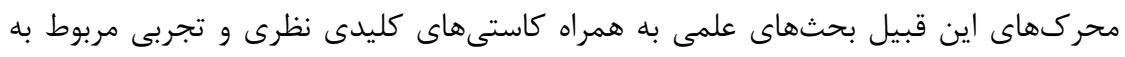

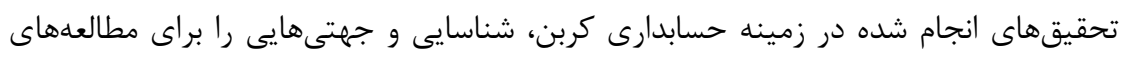

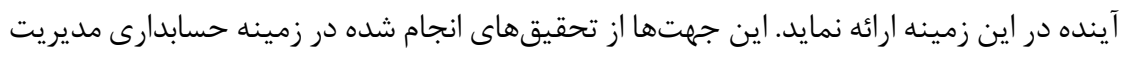

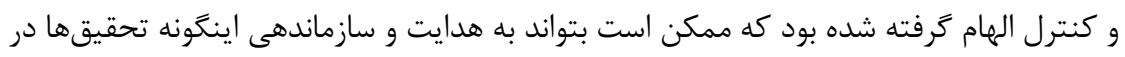

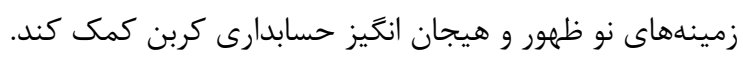


همانطور كه مشاهده شد، در اين بخش يزوهشهاى مرتبط از منظر مفهومى و تحليلى مورد

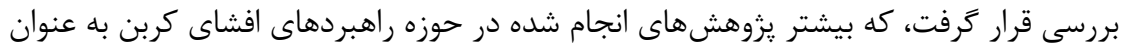

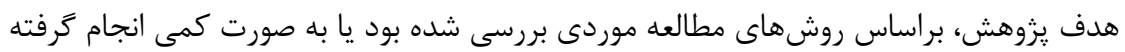

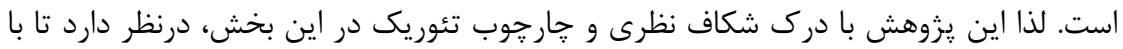

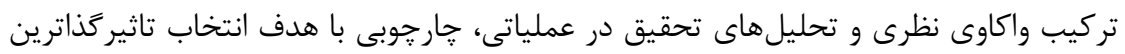
راهبرد افشاى كربن ارائه نمايد.

\section{r - سوال ها و فرضيه يزوهش}

سوالهاى بخش كيفى اين يزوهش به به شرح ذيل ذيل هستند: كزارههاى فشار اجتماعى در سطح شركتهاى باز باز سرار سرايه كدامند؟

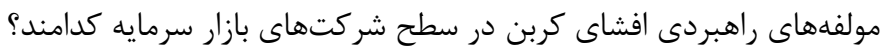

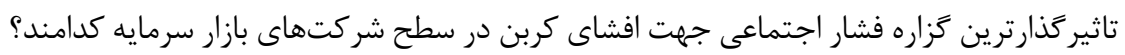

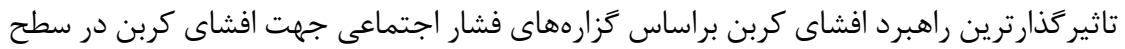

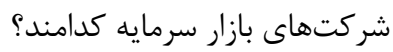

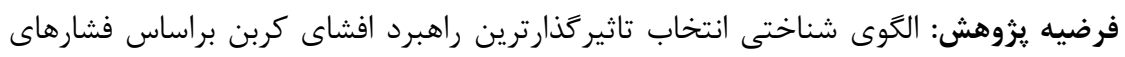
اجتماعى ذينفعان در سطح بازار سرمايه عملكرد مناسبى دارد. F - روش شناسى يزوهش

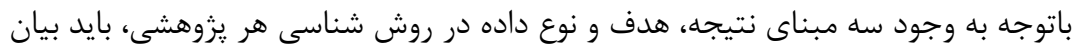

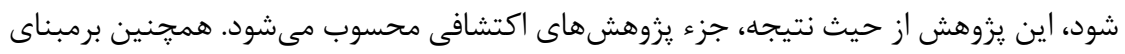

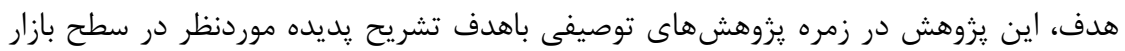

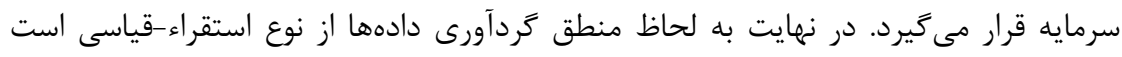

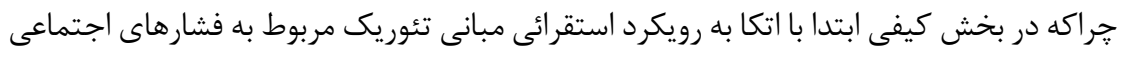

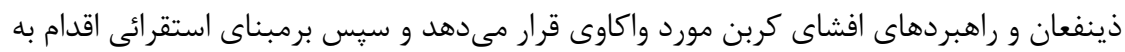

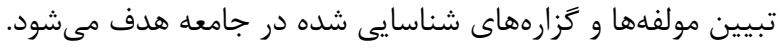

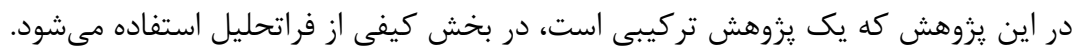

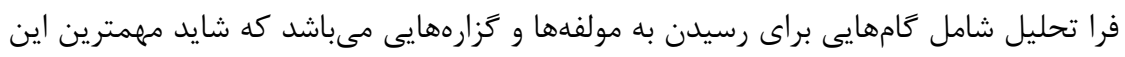

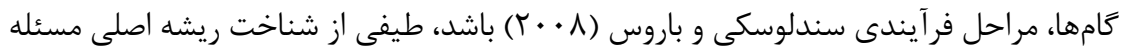

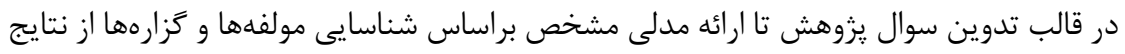

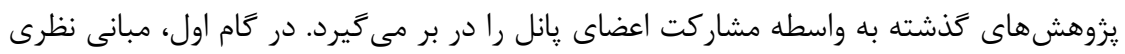


و يزوهشى مرتبط با كزارهها و مولفهاى يزوهش كه شامل V9 يزوهش بودند، تعيين شد و سيس

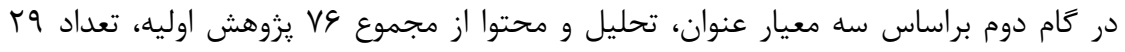

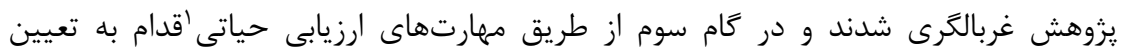

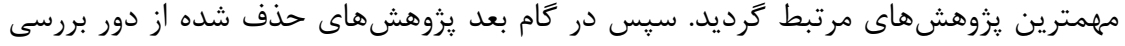

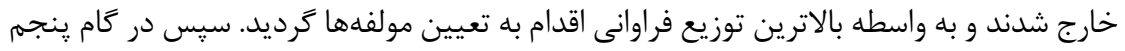

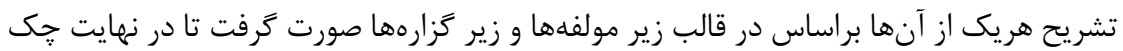

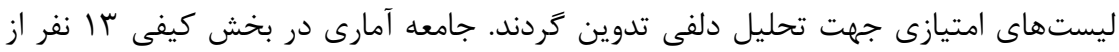
متخصصان حسابدارى و مشاوران زيستمحيطى در سطح دانشخاهى و شركتهاى دارئ بازار سرمايه

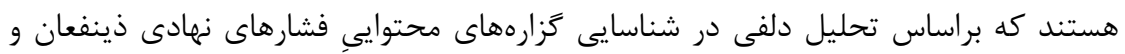
مولفه هاى راهبرد افشاى كربن مشاركت دارند. به منظور انتخاب اين افراد از شيوه نمونه دانيرى كيفى همكن در قالب اعضاى گروه پانل استفاده شده است.

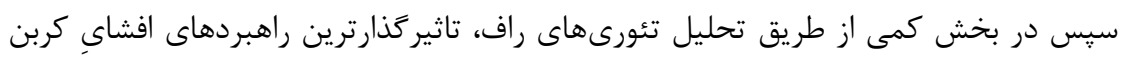

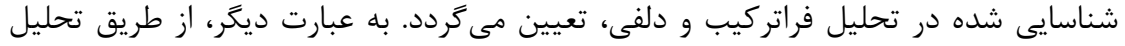

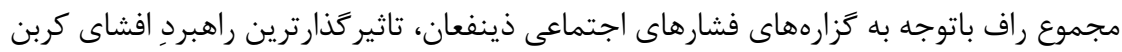

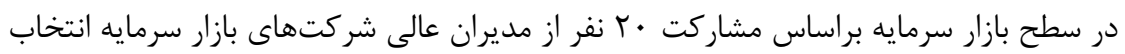

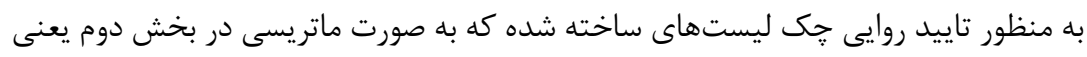

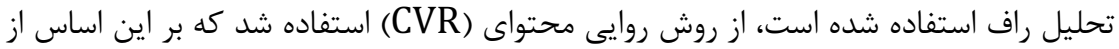

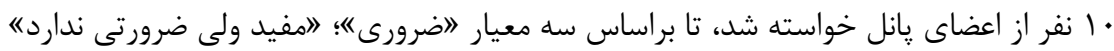

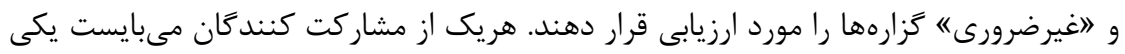

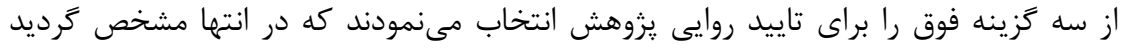

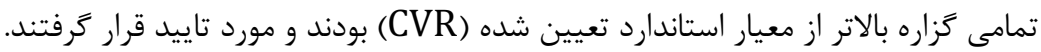

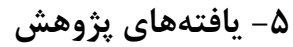

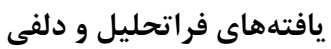

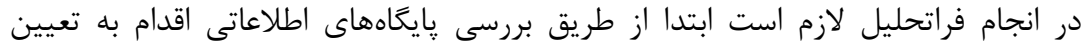

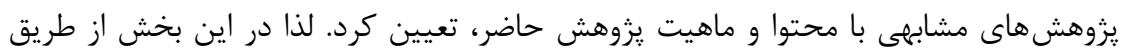

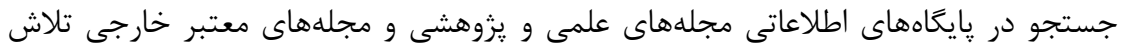

${ }^{1}$ critical appraisal skills programme (CASP) 
كرديد تا در كام اول يزوهشهاى مرتبط انتخاب كردند و سيس براساس فرآيندهاى تحليلى اين

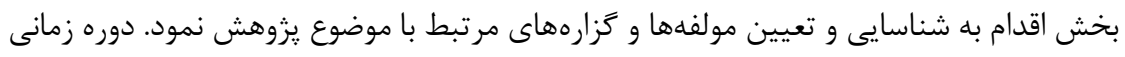

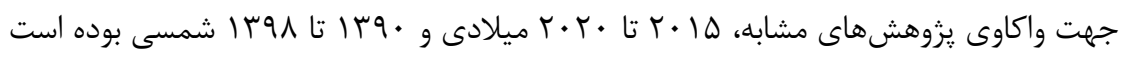

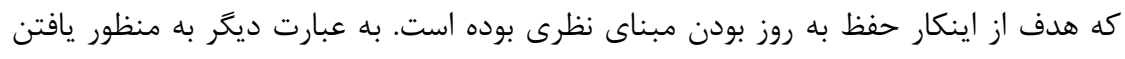

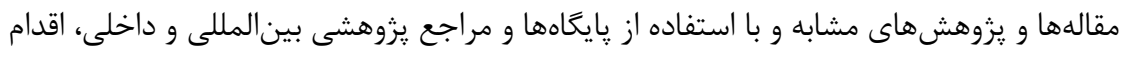

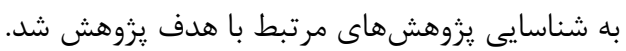
شكل (1) غربالكرى يزوهشهاى اوليه

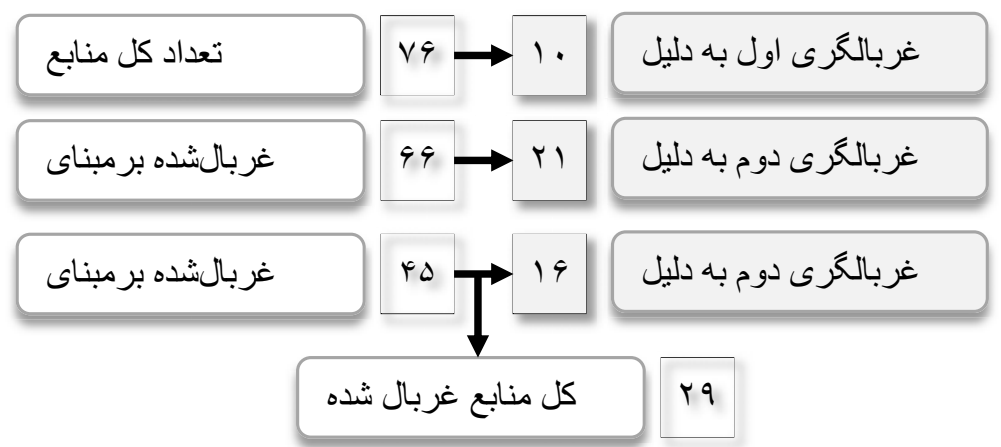

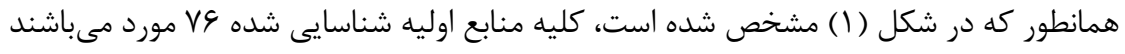

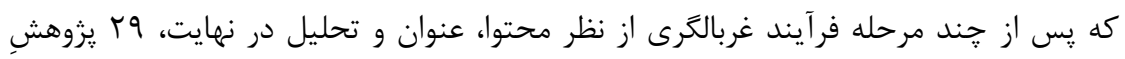

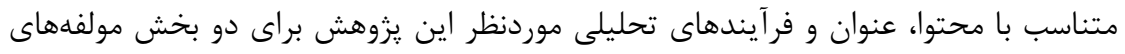

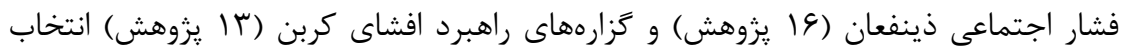

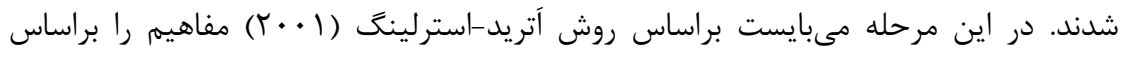

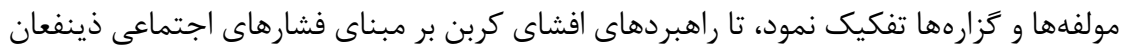

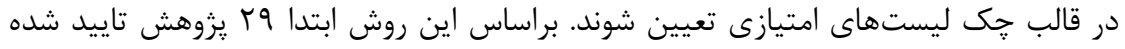

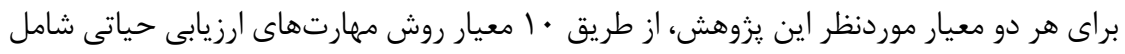

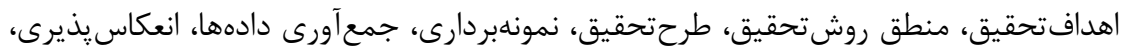

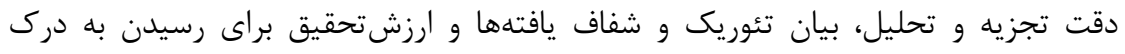

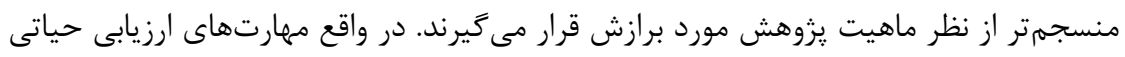

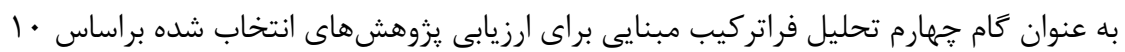
معيار ياد شده مى باشد.

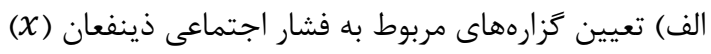



امانى بابادى، الكوى شناختى انتخاب تاثير تذار ترين راهبرد افشاى كربن براساس فشارهاى ...

در اين بخش همانطور كه تشريح شد، با اتكا به روش استرلينگ ( ( • ب) براساس فراتركيب و

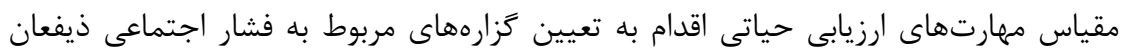

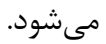

جدول (1) فر آيند ارزيابى يزوهشهاى تاييد شده جهت تعيين كزاره فشار ذينفعان

\begin{tabular}{|c|c|c|c|c|c|c|c|c|c|c|c|c|c|c|c|c|}
\hline \multicolumn{6}{|c|}{ يزروهشهاى داخلى } & \multicolumn{10}{|c|}{ يزوهشهاى خارجى } & \\
\hline 19 & 10 & $1 f$ & سו & $1 T$ & 11 & 1. & 9 & $\wedge$ & V & 9 & $\Delta$ & $r$ & r & $r$ & 1 & \\
\hline $\begin{array}{l}\frac{2}{3} \\
y \\
\hat{a} \\
\frac{\sigma}{2} \\
z\end{array}$ & $\begin{array}{l}\hat{3} \\
\xi \\
\sigma \\
3 \\
3 \\
3\end{array}$ & 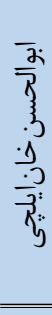 & 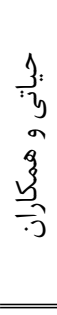 & 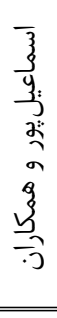 & 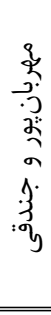 & $\begin{array}{c}3 \\
\dot{3} \\
\sigma \\
a \\
3 \\
3 \\
\frac{3}{.5}\end{array}$ & 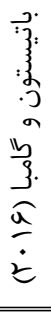 & 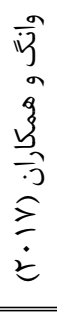 & $\begin{array}{l}\frac{12}{59} \\
\frac{3}{3} \\
\frac{9}{3} \\
\overline{3} \\
\frac{3}{8} \\
\frac{5}{2}\end{array}$ & $\begin{array}{c}3 \\
3 \\
3 \\
0 \\
3 \\
3 \\
-3 \\
-3\end{array}$ & 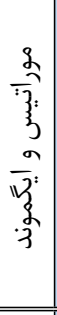 & 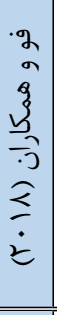 & $\begin{array}{c}1 \\
\vdots \\
\sigma \\
\sigma \\
\vdots \\
\sigma \\
\frac{\sigma}{2} \\
\dot{z}\end{array}$ & 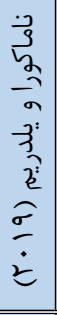 & $\begin{array}{c}3 \\
y \\
5 \\
3 \\
\sigma \\
3 \\
3 \\
-3 \\
.3\end{array}$ & \\
\hline$\nabla$ & $\nabla$ & -- & $\nabla$ & $\nabla$ & $\nabla$ & $\nabla$ & $\nabla$ & $\nabla$ & $\nabla$ & $\nabla$ & $\nabla$ & -- & $\nabla$ & -- & -- & ل إييد \\
\hline & & 凶 & & & & & & & & & & 凶 & & 口 & $\boldsymbol{x}$ & حذف \\
\hline r & r & $r$ & $\Delta$ & f & $r$ & $r$ & r & r & f & r & f & $r$ & f & $r$ & r & هدف \\
\hline$r$ & f & r & $\Delta$ & f & $r$ & f & r & f & r & f & $r$ & $r$ & r & r & $r$ & روش \\
\hline f & f & $r$ & f & f & f & f & $r$ & $r$ & f & $r$ & f & $r$ & f & $r$ & $r$ & طرح \\
\hline r & f & $r$ & $\Delta$ & f & $r$ & r & f & f & k & f & f & $r$ & f & $r$ & r & نمونه \\
\hline r & $r$ & $r$ & r & $\Delta$ & $r$ & f & $r$ & f & $\Delta$ & f & $r$ & $r$ & r & $r$ & r & داده \\
\hline$r$ & f & r & $\Delta$ & f & f & f & f & r & f & f & f & $r$ & f & $r$ & $r$ & تعميمم \\
\hline f & r & r & f & f & $r$ & r & f & f & $\Delta$ & $r$ & k & $r$ & f & $r$ & $r$ & اخلاق \\
\hline r & f & $r$ & f & $\Delta$ & f & f & r & f & $\Delta$ & f & $\Delta$ & $r$ & r & $r$ & $r$ & تحليل \\
\hline$r$ & f & f & f & f & r & $\Delta$ & f & r & r & f & $r$ & $r$ & r & $r$ & $r$ & تئورى \\
\hline$r$ & f & $r$ & $\Delta$ & $\Delta$ & r & f & f & f & f & f & r & $r$ & f & $r$ & r & ارزش \\
\hline$r \Delta$ & rᄉ & $r \Delta$ & $F \Delta$ & Fr & ra & $f$. & ry & rs & rq & rV & ऍ^ & $r \Delta$ & rq & TF & $r \Delta$ & جمع \\
\hline
\end{tabular}

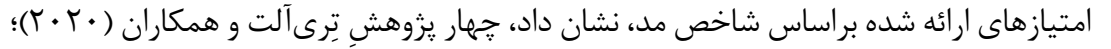

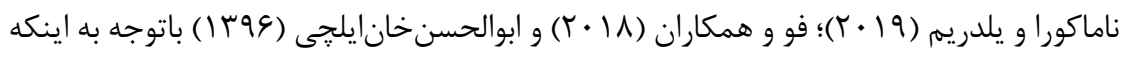

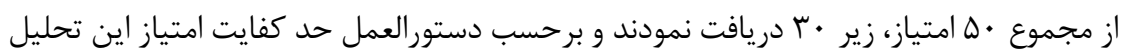

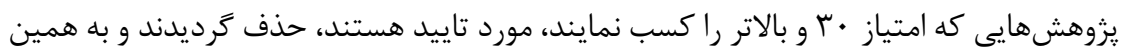




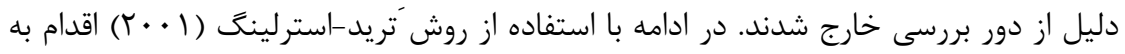

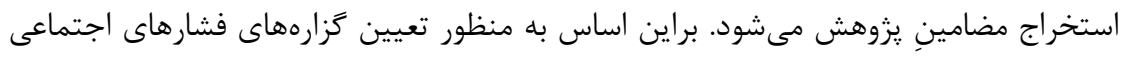

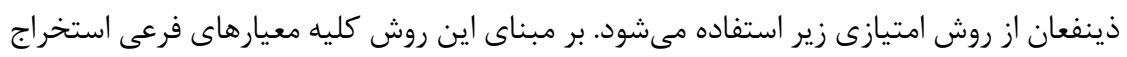

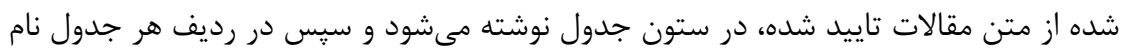

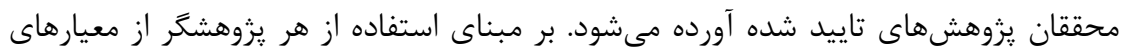

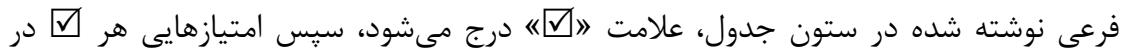

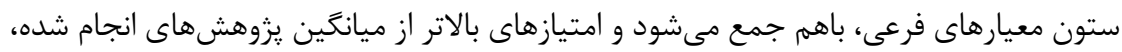

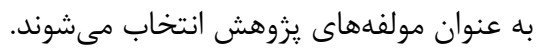
جدول (r) فر آيند تعيين مولفههاى اصلى يزولش

\begin{tabular}{|c|c|c|c|c|c|c|}
\hline $\begin{array}{l}\frac{3}{3} \\
\frac{\pi}{3} \\
\frac{3}{3} \\
\frac{3}{3} \\
\frac{9}{3}\end{array}$ & $\begin{array}{l}3 \\
\overline{3} \\
3 \\
4 \\
3 \\
3 \\
3 \\
3\end{array}$ & $\begin{array}{l}3 \\
\frac{3}{3} \\
3 \\
4 \\
50 \\
5 \\
5 \\
5 \\
3\end{array}$ & $\begin{array}{l}3 \\
\frac{3}{3} \\
\overline{3} \\
3 \\
4 \\
3 \\
3 \\
3 \\
3\end{array}$ & $\begin{array}{c}3 \\
\overline{3} \\
\overline{3} \\
3 \\
y \\
3 \\
\vdots \\
y \\
3 \\
\overline{9} \\
9 \\
9\end{array}$ & $\begin{array}{c}3 \\
\overline{3} \\
\overline{3} \\
3 \\
y \\
3 \\
y \\
2 \\
2 \\
3 \\
\frac{13}{3}\end{array}$ & محققان \\
\hline \multirow[t]{2}{*}{$\nabla$} & - & - & $\nabla$ & - & - & جيئو و شو (Y.19) \\
\hline & - & - & $\nabla$ & $\nabla$ & - & موراتيس و ايخموند (Y) (Y) \\
\hline$\nabla$ & $\nabla$ & - & $\nabla$ & $\nabla$ & - & 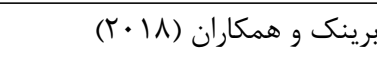 \\
\hline$\nabla$ & - & - & - & - & - & كرافالند و اسميد (Y (Y) \\
\hline$\nabla$ & - & - & $\nabla$ & $\nabla$ & $\nabla$ & وانگ و همكاران (Y. IV) \\
\hline$\nabla$ & $\nabla$ & - & - & $\nabla$ & - & باتيستون و كامبا (1) · · ) \\
\hline$\nabla$ & - & - & $\nabla$ & $\nabla$ & - & برينك و همكاران (19 • r) \\
\hline- & $\nabla$ & - & - & - & $\nabla$ & مهربان يور و جندقى قمى (1 ( I ) \\
\hline- & - & $\nabla$ & - & - & $\nabla$ & سماعيل يور و همكاران (1 (1) \\
\hline- & $\nabla$ & - & - & $\nabla$ & - & حياتى و همكاران (1 (1) (1) \\
\hline- & - & $\nabla$ & $\nabla$ & $\nabla$ & - & حسينى و خوئينى (9 (I) \\
\hline$\nabla$ & - & $\nabla$ & - & - & - & مرادى (هو (1) \\
\hline$v$ & r & r & 9 & V & $r$ & جمع \\
\hline
\end{tabular}


براساس اين تحليل مهارتهاى ارزيابى حياتى نيز مشخص شد، سه مولفه فشار اجتماعى إنى

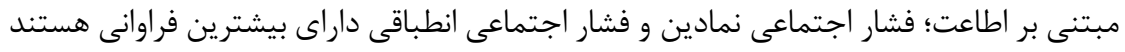

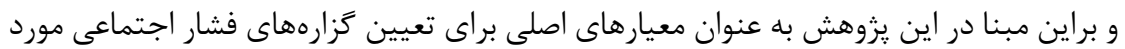

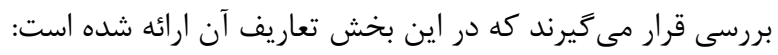

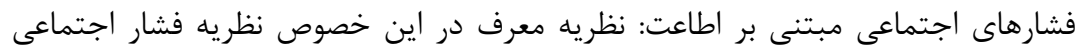

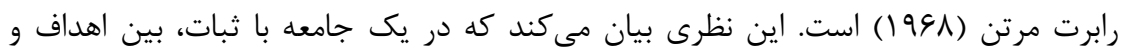

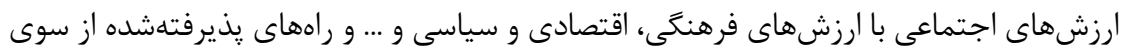

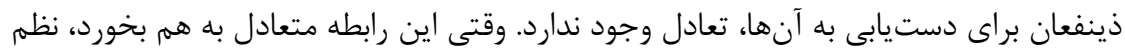

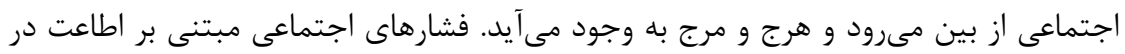

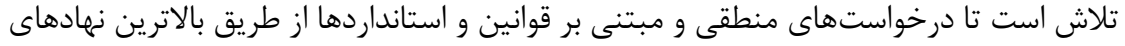

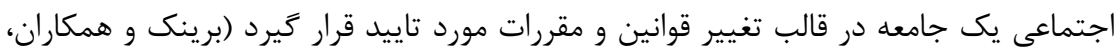

فشارهاى اجتماعى مبتنى بر انطباقى بودن: اين نوع از فشار اجتماعى، سطحى از هنجارهاى

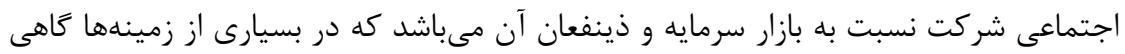

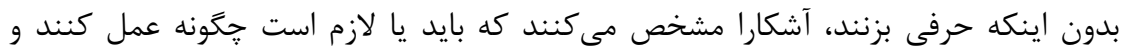

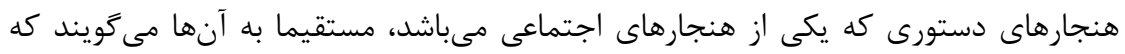

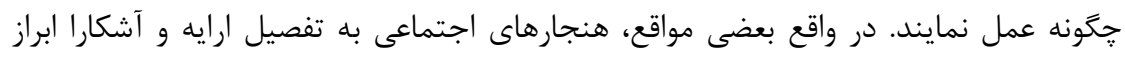

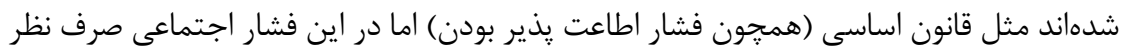

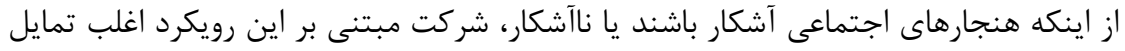

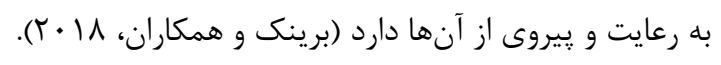

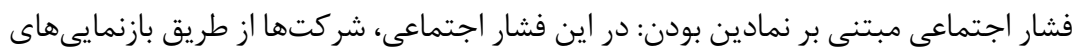

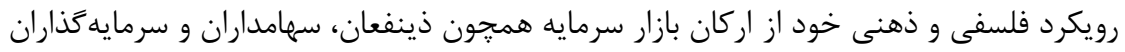

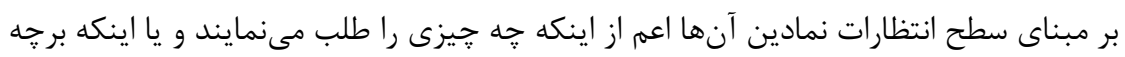

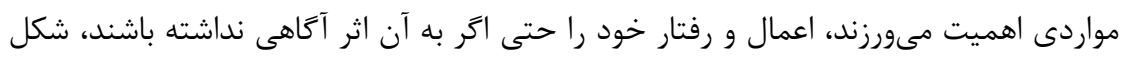
نمادين مىدهند. اين فشار اجتماعى مى تواند ناشى از قرار كرفتن شركا

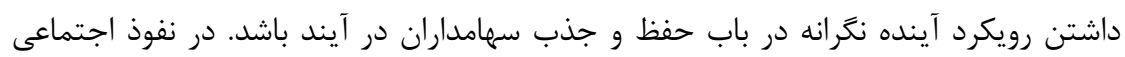

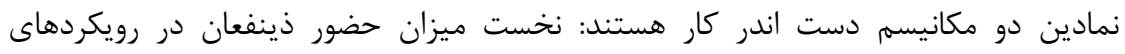

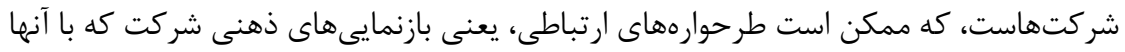

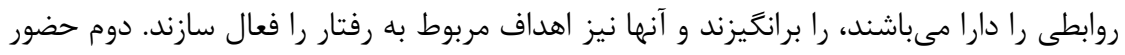


روانشناختى ذينفعان ممكن است هدفهايى را برانگيزد كه آن شركت به آن مربوط هستند، يعنى

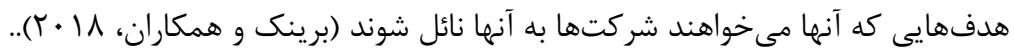

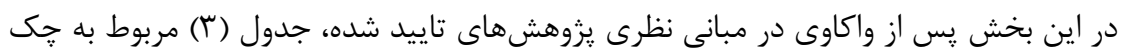
ليستهاى دلفى ارائه شده است. در واقع بهمنظور اطمينان از خزارههاى شناسايى شده از تحليل

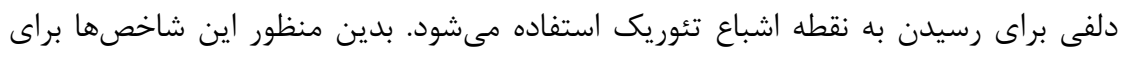

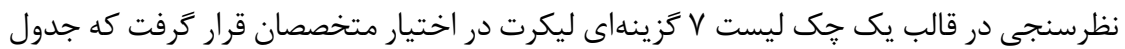

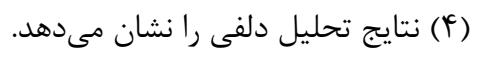

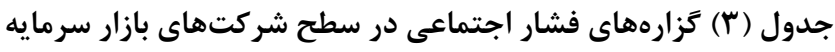

\begin{tabular}{|c|c|c|c|c|c|c|c|}
\hline 1 & $r$ & $r$ & f & $\Delta$ & $\mathrm{V}$ & |زير ززارهها & كزار \\
\hline & & & & & & 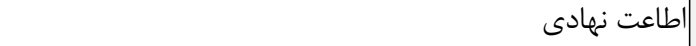 & \\
\hline & & & & & & 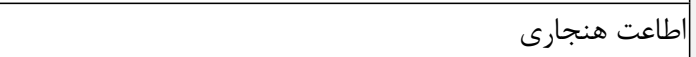 & \\
\hline & & & & & & | اطاعت استانداردى & 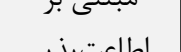 \\
\hline & & & & & & | اطاعت سياسى & "ֶיטנ \\
\hline & & & & & & | اعت قانونى & \\
\hline & & & & & & تمايل به يذيرش شدن اجتماعى & \\
\hline & & & & & & تمايل به آكاهى از ادراك درست از واقعيتها (سطح انتطارات) & فشار اجتماعى \\
\hline & & & & & & تمايل به نزديك شدن به منبع قدرت (جذب سهامداران بيشتر) & مبتنى بر \\
\hline & & & & & & تمايل به هنجارهاى تغيير يافته اجتماعى & | انطباقى بودن \\
\hline & & & & & & تمايل به حفظ آرامش روانشناختى & \\
\hline & & & & & & تحريك حس يكيارجّگى سهامداران در ارائه اطلاعات نمادين & \\
\hline & & & & & & حجيم نشان دادن اهميت انتظارات سهامداران و سرمايهَذاران & \\
\hline & & & & & & ك شركت & مبتنحي بر \\
\hline & & & & & & حجيم نشان دادن جذب سرمايههاى نقدى از بازار & \\
\hline & & & & & & حجيم نشان دادن سطح نظارتها بر منافع سهامداران & \\
\hline & & & & & & |حجيم جلوه دادن ميزان يذيرش جمعى سمامداران & \\
\hline
\end{tabular}

استفاده از طيف ليكرت V ₹زينهاى به اين دليل بود كه با فاصله كم يا زياد، مولفهها و ززارهها

$$
\text { بهتر مورد بررسى قرار گيرند. }
$$




$$
\text { اول مورد تاييد قرار گرفتند. براساس گزارههاى تاييد شده، جارجوب فشارهاى اجتماعى ذينفعان }
$$

شكل (r) جارجوب فشارهاى اجتماعى ذينفعان در بازار سرمايه

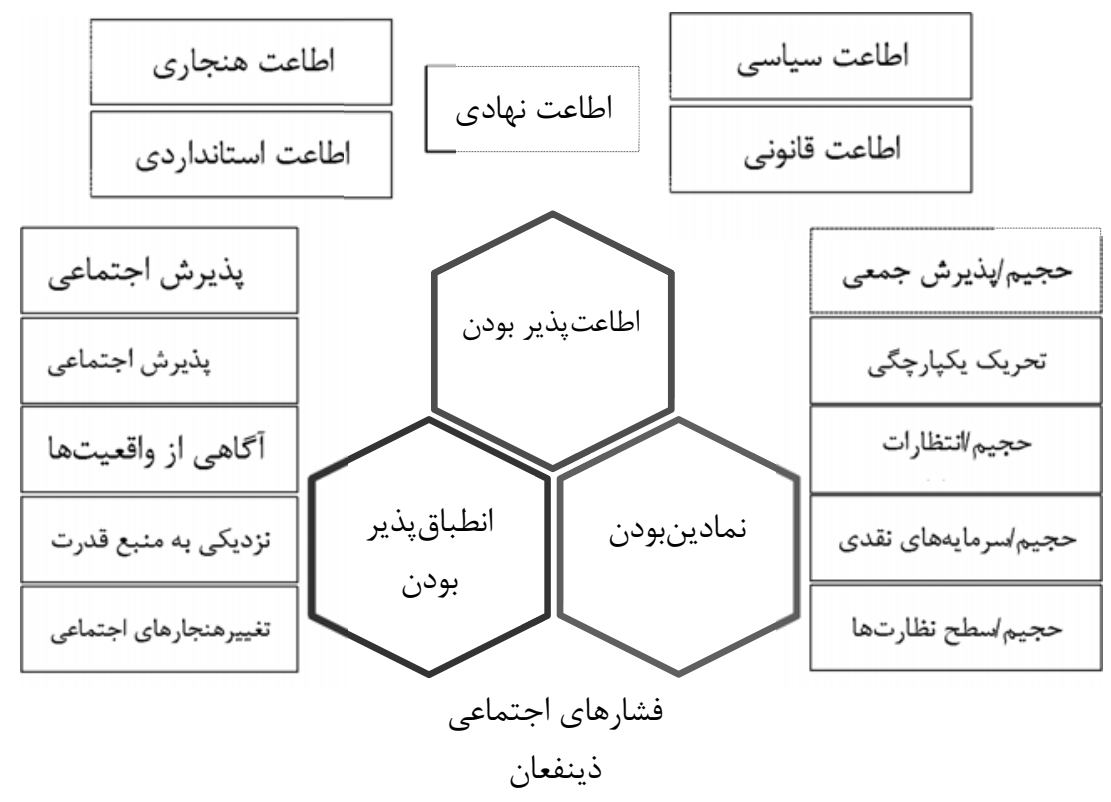

ب) تعيين مولفههاى راهبردى افشاى كربن (y) همانند بخش قبلى براى استخراج مولفههاى مرتبط با راهبردِ افشاى كربن به عنوان مبنا (قانون در فرآيند تحليل راف) براساس مقياس مهارتهاى ارزيابى حياتى اقدام به تعيين مولفههاى مرتبط به اين بخش در سطح بازار مىشود. 

امانى بابادى، الكوى شناختى انتخاب تاثير كذارترين راهبرد افشاى كربن براساس فشارهاى ...

جدول (ه) فر آيند ارزيابى يزوهشهاى تاييد شده جهت تعيين مولفهها و كزارههاى يزوهش

\begin{tabular}{|c|c|c|c|c|c|c|c|c|c|c|c|c|c|}
\hline \multicolumn{4}{|c|}{ يزوهشهاى داخلى } & \multicolumn{9}{|c|}{ يزوهش هاى خارجى } & \multirow[b]{3}{*}{ يزوهشها } \\
\hline $1 \pi$ & $1 T$ & 11 & 1. & 9 & $\wedge$ & $V$ & $q$ & $\Delta$ & f & r & $r$ & 1 & \\
\hline \multirow[t]{2}{*}{ 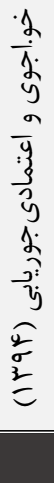 } & 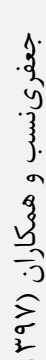 & 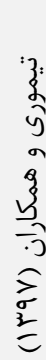 & 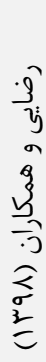 & $\begin{array}{l}3 \\
5 \\
5 \\
\frac{5}{5} \\
\frac{5}{5} \\
\frac{1}{5}\end{array}$ & 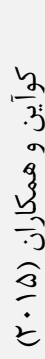 & 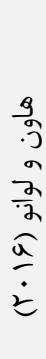 & 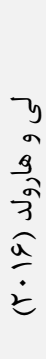 & 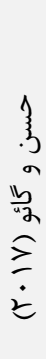 & 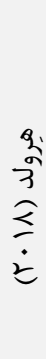 & 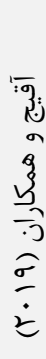 & 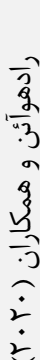 & $\begin{array}{l}\overline{3} \\
3 \\
\dot{3} \\
\dot{2} \\
\dot{2}\end{array}$ & \\
\hline & $\bar{\nabla} \nabla$ & $\nabla$ & $\nabla$ & $\nabla$ & 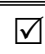 & & & $\nabla$ & $\nabla$ & & & $\nabla$ & تاييد \\
\hline 区 & & & & & & $\mathbf{x}$ & $\mathbf{x}$ & & & $\mathbf{x}$ & $\mathrm{x}$ & & حذف \\
\hline$r$ & f & r & r & r & f & r & $r$ & $r$ & f & r & $r$ & r & هدف \\
\hline r & f & f & r & f & $\Delta$ & r & r & r & f & r & 1 & r & 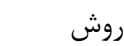 \\
\hline$r$ & r & r & i & f & f & $r$ & r & $r$ & r & r & $r$ & r & طرح \\
\hline$r$ & f & f & r & r & f & r & r & r & i & r & r & i & نمونه \\
\hline$r$ & f & f & f & f & f & 1 & $r$ & $r$ & f & r & $r$ & $r$ & 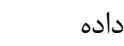 \\
\hline 1 & f & f & $r$ & r & f & r & r & r & r & r & r & r & تعميم \\
\hline$r$ & f & $f$ & f & r & f & $r$ & $r$ & $r$ & f & $r$ & $r$ & $r$ & اخلاق \\
\hline$r$ & f & f & f & f & r & r & $r$ & r & f & r & r & $r$ & تحليل \\
\hline r & f & $f$ & $r$ & f & f & $r$ & $r$ & r & r & f & $r$ & r & تئورى \\
\hline$r$ & f & f & $r$ & f & $\Delta$ & $r$ & $r$ & $r$ & f & r & $r$ & r & ارزش \\
\hline r & rq & rᄉ & $r \Delta$ & rV & F & זr & $r q$ & TV & rV & $r \wedge$ & rI & G & جمع \\
\hline
\end{tabular}

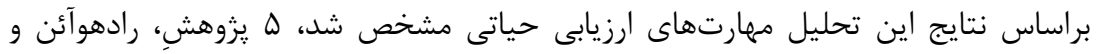

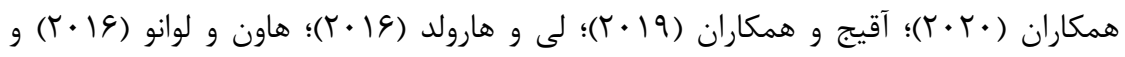

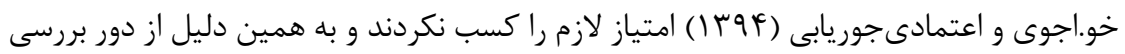

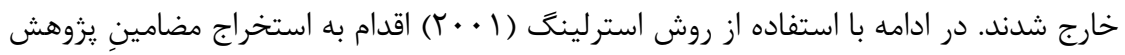

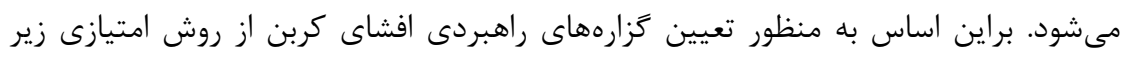
استفاده مىشود. بر مبناى اين روش كليه معيارهاى فرعى استخراج شده از متن مقالات تاييد

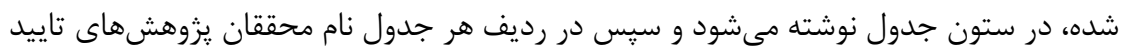


شده آورده مىشود. بر مبناى استفاده از هر يزوهش رَ از معيارهاى فرعى نوشته شده در ستون

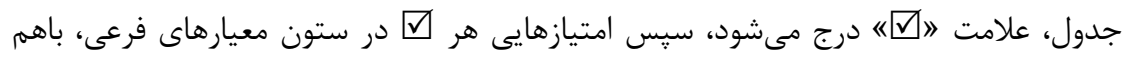

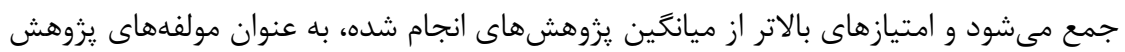

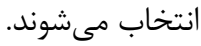

جدول (9) واكاوى مولفههاى اصلى راهبردهاى افشاى كربن

\begin{tabular}{|c|c|c|c|c|c|c|c|}
\hline $\begin{array}{c}\overline{9} \\
\hat{1} \\
\hat{3} \\
y \\
3 \\
2 \\
y \\
\hat{2} \\
\hat{9} \\
\overline{3} \\
3\end{array}$ & 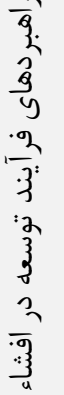 & 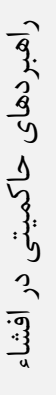 & 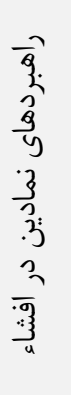 & 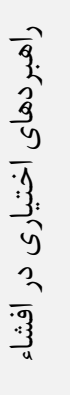 & 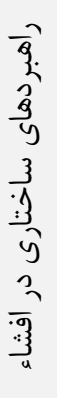 & محققان & ئروهش \\
\hline- & $\nabla$ & - & $\nabla$ & - & - & ايريدل (r.r. (T) & \multirow{6}{*}{ 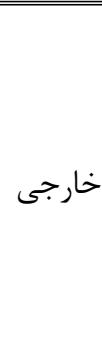 } \\
\hline$\nabla$ & $\nabla$ & - & $\nabla$ & $\nabla$ & - & هِرولد (Y) & \\
\hline - & - & - & $\nabla$ & $\nabla$ & - & ولبك (Y (Y.) & \\
\hline- & $\nabla$ & $\nabla$ & $\nabla$ & - & - & حسن و كائو (YV) & \\
\hline$\nabla$ & $\nabla$ & - & $\nabla$ & $\nabla$ & $\nabla$ & كوآين و همكاران (U) & \\
\hline- & - & $\nabla$ & $\nabla$ & $\nabla$ & - & ساكا و اوسيكا (r) (Y) & \\
\hline- & $\nabla$ & - & - & $\nabla$ & - & رضايى و همكاران (1) (I ) & \multirow{3}{*}{ 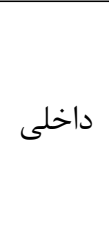 } \\
\hline- & $\nabla$ & $\nabla$ & - & - & - & تيمورى و همكاران (Vq I I) & \\
\hline - & - & $\nabla$ & - & $\nabla$ & - & 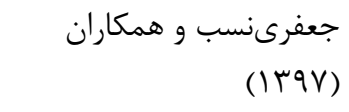 & \\
\hline r & 4 & r & 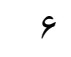 & 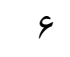 & 1 & & جمع - اع \\
\hline
\end{tabular}

براساس اين تحليل نيز مشخص شد، ب راهبرد اختيارى در افشاى كربن؛ راهبرد نمادين در

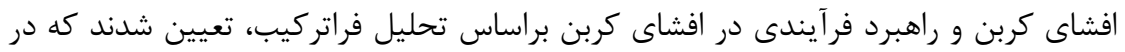

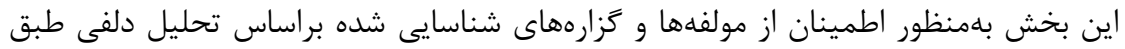
جدول (V) براى رسيدن به نقطه اشباع تئوريك مورد بررسى قرار مئى آنيرند. 

امانى بابادى، الكَوى شناختى انتخاب تاثير تذار ترين راهبرد افشاى كربن براساس فشارهاى ...

جدول (V) مولفهها راهبردى افشاى كربن

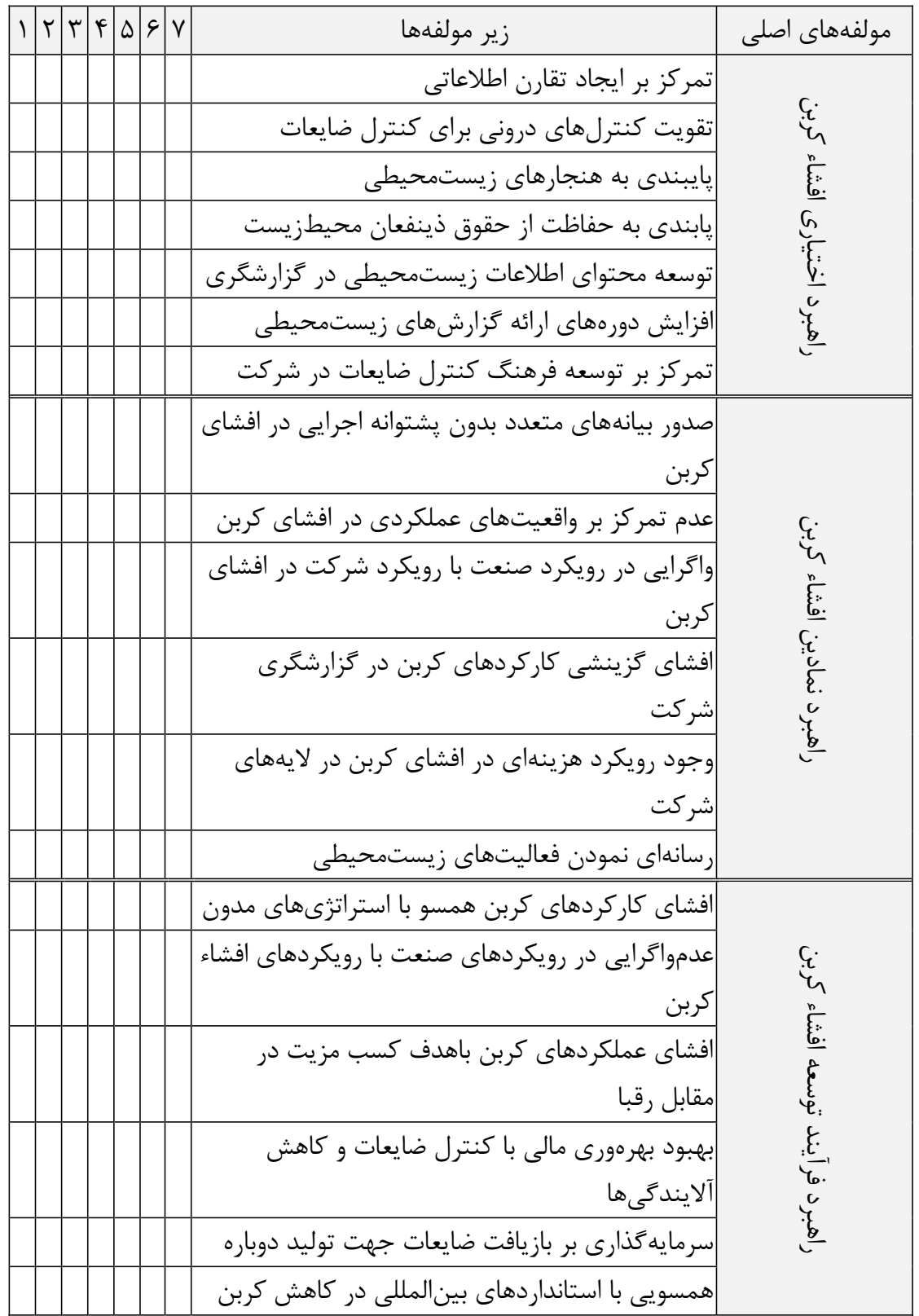


دو فصلنامه حسابدارى ارزشى و رفتارى، سال ينجم، شماره دهم، پِاييز و زمستان وجها

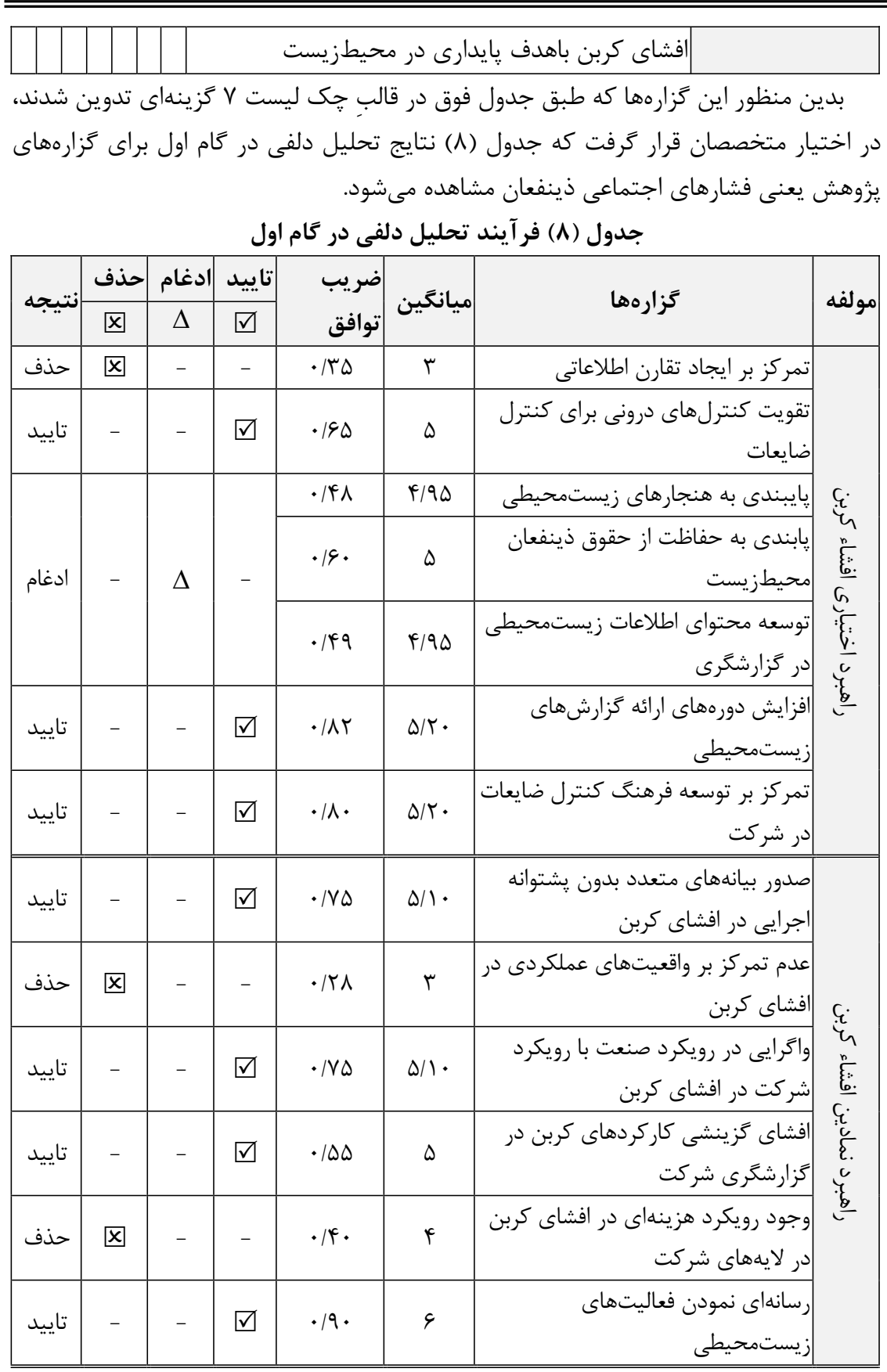


امانى بابادى، الكوى شناختى انتخاب تاثير كذارترين راهبرد افشاى كربن براساس فشارهاى ...

\begin{tabular}{|c|c|c|c|c|c|c|}
\hline تاييد & - & - & $\nabla$ & - IAT & $\Delta / r$. & $\begin{array}{r}\text { افشاى كاركردهاى كربن همسو با } \\
\text { استرىهاى مدون }\end{array}$ \\
\hline حذف & 凶 & & - & $\cdot / T \Lambda$ & r & 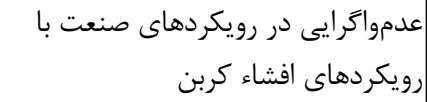 \\
\hline \multirow{2}{*}{ ادغام } & \multirow{2}{*}{ - } & \multirow{2}{*}{$\Delta$} & \multirow{2}{*}{ - } &.$/ 9$. & $\Delta$ & افشاى عملكردهاى كربن باهدف كسب در مقابل رقبا \\
\hline & & & &.$/ 4 q$ & $4 / 90$ & 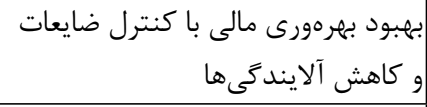 \\
\hline تاييد & - & & $\nabla$ & $\cdot / V \Delta$ & $\Delta / 1$. & سرمايه گذارى بر بازيافت ضايعات جهت \\
\hline تاييد & - & & $\nabla$ & $\cdot \mid \wedge \Delta$ & $\Delta / \Gamma$. & كاهش كمسيى با استانداردهاى بينالمللى در \\
\hline حذف & 凶 & - & - & $\cdot \pi \Delta$ & $r / \Delta$. & |فشاى كربن باهدف يايدارى در \\
\hline
\end{tabular}

براساس تحليل دلفى مشخص شد، ه گزاره حذف شدند، جراكه باتوجه به اينكه براساس مقياس

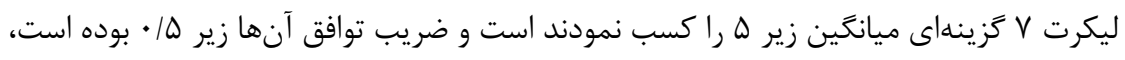

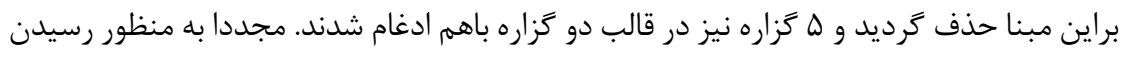
به حدكفايت نظرى، تحليل دلفى انجام مىشود تا يس از تاييد نهايى اقدام به تدوين جارجوب نظرى يروهش به منظور ورود به تحليل تفسيرگرايانه و ساختارمندانه گردد. جدول (q) تحليل راند دوم تحليل دلفى

\begin{tabular}{|c|c|c|c|c|c|c|}
\hline \multirow{2}{*}{ |نتيجه | } & حذف & تاييد & & مانخـ . & \multirow{2}{*}{ تشريح مولفهها } & \multirow{2}{*}{ 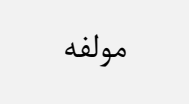 } \\
\hline & 口 & $\square$ & 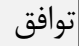 & ي - هي & & \\
\hline تاييد & - & $\nabla$ & $\cdot \mid \wedge \Delta$ & 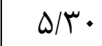 & تقويت كنترل هاى درونى براى كنترل ضايعات & \multirow{4}{*}{ راهبرد اختيارى } \\
\hline 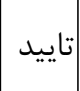 & - & $\nabla$ & $\cdot 1 \Lambda \cdot$ & $\Delta / \tau$. & 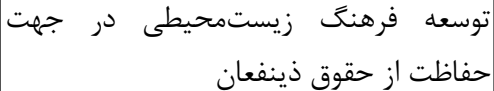 & \\
\hline 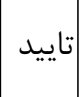 & - & $\nabla$ & $\cdot 1 \Lambda \cdot$ & $\Delta / \zeta \cdot$ & تَزارشكَرى محتواى اطلاعات زيستمحيطى در| & \\
\hline 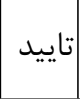 & - & $\nabla$ & • $\mid \wedge \Delta$ & $\Delta / r \Delta$ & 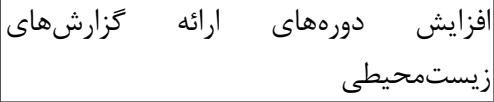 & \\
\hline 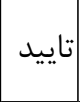 & - & $\nabla$ & $\cdot 1 \Lambda \cdot$ & $\Delta / T \cdot$ & |اتكاء به صدور بيانههاى متعدد بدون يشتوانه & \\
\hline
\end{tabular}


دو فصلنامه حسابدارى ارزشى و رفتارى، سال ينجم، شماره دهم، پِاييز و زمستان و9"1

\begin{tabular}{|c|c|c|c|c|c|c|}
\hline 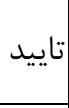 & - & $\checkmark$ & $\cdot 19 \cdot$ & \& & |فشاى كربن در رويكرد صنعت با رويكرد شركت در & \multirow{3}{*}{ فاهشبرد نمادين } \\
\hline تاييد & - & $\checkmark$ & $\cdot / V D$ & $\Delta / 1 \cdot$ & 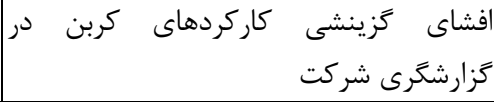 & \\
\hline تاييد & - & $\nabla$ & $\cdot 19$. & \& & رسانهاى نمودن فعاليتهاى زيستمحيطى & \\
\hline 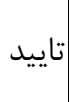 & - & $\square$ & $\cdot / \Lambda \Delta$ & $\Delta / \Gamma \cdot$ & استراترى اطلاعاى مدون كاركردهاى كربن همسو با| & \multirow{4}{*}{ كربعه افشبرد فرآيند } \\
\hline تاييد & - & $\checkmark$ & $\cdot / \Lambda \cdot$ & $\Delta / r \cdot$ & جهت كسب مزلكردهاى كربن باء هدف رِايدارى & \\
\hline 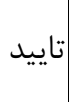 & - & $\checkmark$ & $\cdot / \Lambda \Delta$ & $\Delta / T \Delta$ & 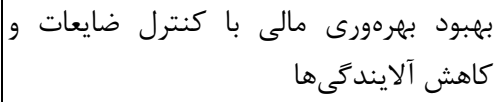 & \\
\hline 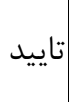 & - & $\checkmark$ & $\cdot / \Lambda \Delta$ & $\Delta / \Gamma \cdot$ & دوباره & \\
\hline
\end{tabular}

همانطور كه مشاهده مىشود تمامى كزارهها در دوم تحليل دلفى تاييد شدند كه نشاندهنده نقطه كفايت نظرى كزارههاى راهبردى افشاى كربن مىباشد. براساس مولفهونهاى تاييد شده، الكوى زير جهت شناخت راهبردهاى افشاء كربن ارائه شده است:

شكل (r) الكوى راهبرد افشاى كربن

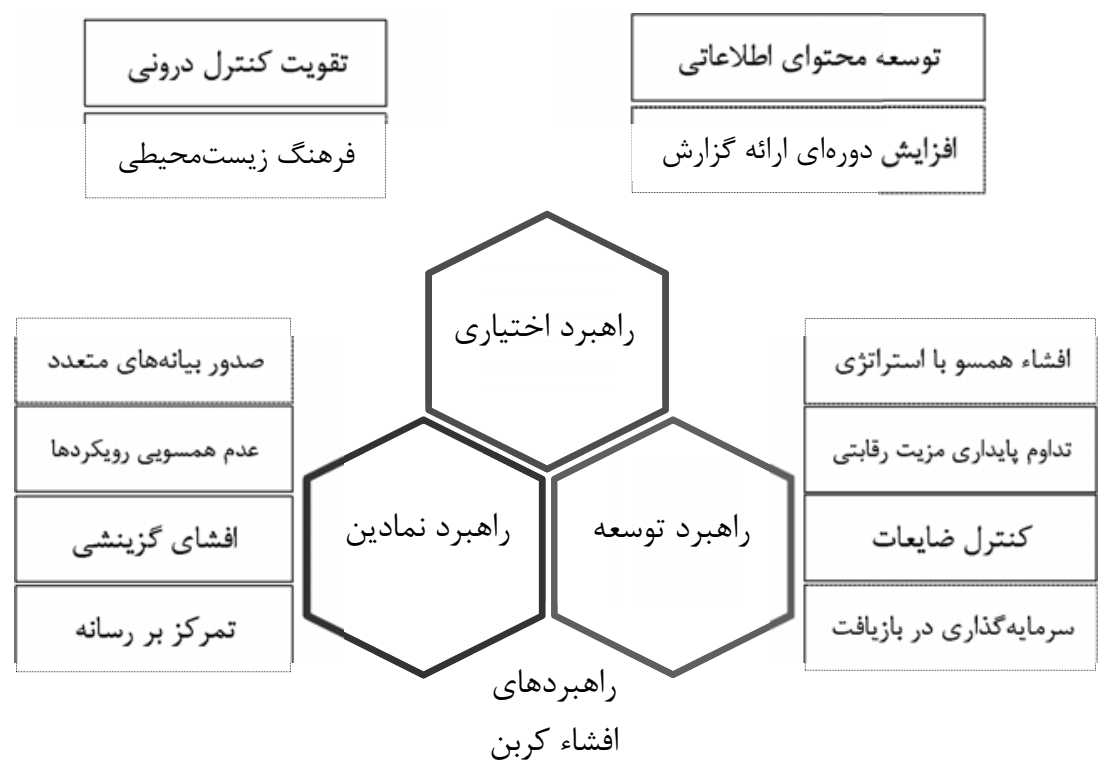


در اين مرحله به منظور انجام كام اول و مشخص نمودن وزن معيارها باتوجه به به تفكيك متغيرهاى مرجع از متغيرهاى قانون و به منظور درك بهتر و استنباط قابلتوجهتر از كدان كدكذارى

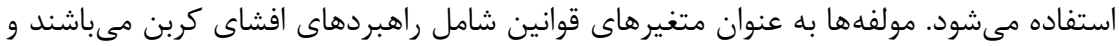

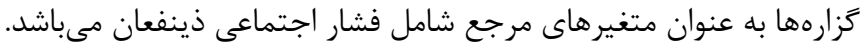

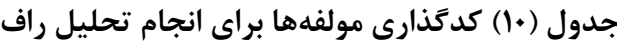

\begin{tabular}{|c|c|c|}
\hline كدهاى مولفههاى & عناصر & 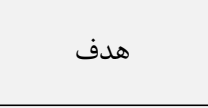 \\
\hline N1 & |راهبرد اختيارى افشاء كربن & \multirow{3}{*}{ راهبردهاى افشاى } \\
\hline $\mathrm{N} 2$ & |راهبرد نمادين افشاء كربن & \\
\hline N3 & |راهبرد فرآيند توسعه افشاء كربن & \\
\hline M1 & 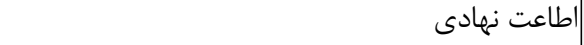 & \multirow{14}{*}{ اجزارههاى فشار } \\
\hline M2 & | اطاعت هنجارى & \\
\hline M3 & | اطاعت استانداردى & \\
\hline M4 & | اعاعت قانونى & \\
\hline M5 & |تمايل به يذيرش شدن اجتماعى & \\
\hline M6 & تمايل به آكاهى از ادراك درست از واقعيتها & \\
\hline M7 & |تمايل به نزديك شدن به منبع قدرت & \\
\hline M8 & تمايل به هنجارهاى تغيير يافته اجتماعى & \\
\hline M9 & تمايل به حفظ آرامش روانشناختى & \\
\hline M10 & تحريك حس يكيارجّى سهرامداران در ارائه اطلاعات & \\
\hline M11 & حجيم نشان دادن اهميت انتظارات سهامداران & \\
\hline M12 & حجيم نشان دادن جذب سرمايههاى نقدى از بازار & \\
\hline M13 & حجيم نشان دادن سطح نظارتها بر منافع سهامداران & \\
\hline M14 & حجيم جلوه دادن ميزان يذيرش جمعى سهامداران & \\
\hline
\end{tabular}

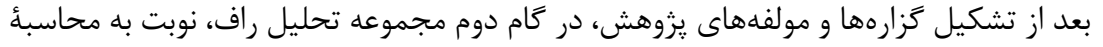

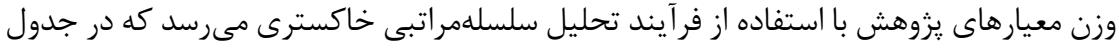

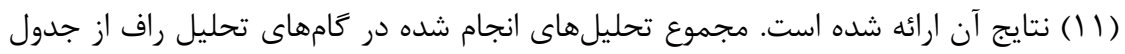
(II) تا جدول (If) جهت ياسخ به سوال سوم يزوهش مى (II)

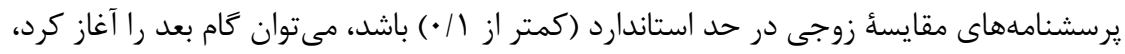


در غير اين صورت يرسشنامههاى مقايسُٔ زوجى به مشاركتكنندًان بازَردانده مىشوند تا

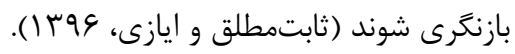
جدول (I) نتايج فرايند تحليل سلسله مراتبى خاكسترى لاري

\begin{tabular}{|c|c|c|c|c|c|c|c|}
\hline \multicolumn{2}{|c|}{ 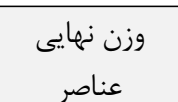 } & \multicolumn{2}{|c|}{ 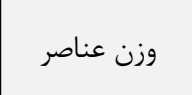 } & \multirow{2}{*}{ 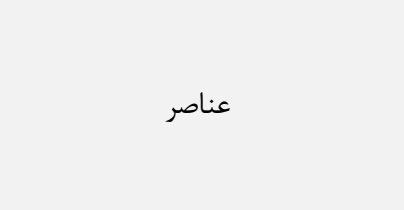 } & \multicolumn{2}{|c|}{ وزن معيارها } & \multirow{2}{*}{ هداف } \\
\hline \begin{tabular}{c|} 
حدبالا \\
(U)
\end{tabular} & $\begin{array}{l}\text { حديايين } \\
\text { (L) }\end{array}$ & \begin{tabular}{|c|} 
حدبالا \\
(U)
\end{tabular} & $\begin{array}{c}\text { حديايين } \\
\text { (L) }\end{array}$ & & \begin{tabular}{|c|} 
حدبالا \\
(U)
\end{tabular} & \begin{tabular}{|c} 
حديايين \\
(L)
\end{tabular} & \\
\hline • I TSK & $\cdot / 491$ & $\cdot \mid r q \mu$ & $\cdot / r \wedge 1$ & راهبرد اختيارى افشاء كربن & \multirow{3}{*}{$\cdot / \Lambda \mathrm{V}$} & \multirow{3}{*}{$\cdot / \mathrm{Vq}$} & \multirow{3}{*}{ كربن } \\
\hline$\cdot / T \Delta F$ & $\cdot / 111$ & $\cdot / T \Delta F$ & .1194 & راهبرد نمادين افشاء كربن & & & \\
\hline$\cdot / 4 \cdot \Delta$ & $\cdot / \mu \cdot \Lambda$ & $\cdot / 4 \cdot \Delta$ &.$/ 419$ & راهبرد فرآيند توسعه افشاء كربن & & & \\
\hline$\cdot|r| f \mid$ & $\cdot|r| 9$ & $\cdot \pi \mid \mathrm{F}$ & - RTY & طاعت نهادى & \multirow{14}{*}{ 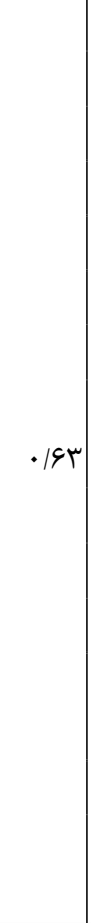 } & \multirow{14}{*}{$\cdot / 49$} & \multirow{14}{*}{ 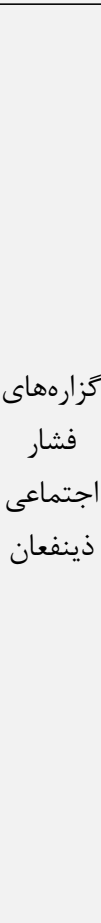 } \\
\hline - & $\cdot / 494$ & $\cdot / 9 \mathrm{TV}$ & $. / 0 \mid V$ & اطاعت هنجارى & & & \\
\hline$\cdot / T I V$ & $\cdot / 149$ & $\cdot / T I V$ &.$/ 1 \Delta f$ & طاعت استانداردى & & & \\
\hline$\cdot|\Delta| \cdot$ & $\cdot / 4 \cdot r$ & $\cdot|0| \cdot$ & . & اطاعت قانونى & & & \\
\hline$\cdot|4| 9$ & $\cdot / 499$ & $\cdot / 4 \mid 4$ & . ITTD & تمايل به پذيرش شدن اجتماعى & & & \\
\hline$\cdot \mid \Lambda \Lambda F$ & - $/ \Delta T Y$ & $\cdot \mid \Lambda \lambda \uparrow$ & $\cdot|\Delta \Delta|$ & تمايل به آكاهى از ادراك درست & & & \\
\hline $.199 \wedge$ & $\cdot / 4 \cdot q$ & .1991 & $\cdot / F \Delta H$ & تمايل به نزديك شدن به منبع قدرت & & & \\
\hline$\cdot / r \wedge q$ & . 1190 & $\cdot / r \wedge 9$ & $\cdot / r \cdot 9$ & جتماعيل به هنجارهاى تغيير يافته & & & \\
\hline$\cdot / \mathrm{V} \wedge$ &.$|9| \cdot$ & $\cdot / N Y A$ & .1999 & تمايل به حفظ آرامش روانشناختى & & & \\
\hline$\cdot \mid 9 \mu \cdot$ &.$/ 4 \vee q$ & $\cdot \mid 94$. &.$/ 01 Y$ & تحريك حس يكيار קكى سهامداران & & & \\
\hline$\cdot / \pi \Lambda \cdot$ &.$/ T \& 4$ & $\cdot / r \Lambda \cdot$ &.$/ r 91$ & حجيم نشان دادن اهميت انتظارات & & & \\
\hline$\cdot|\mu| Y$ & $\cdot / R V$ & $\cdot|F| T$ & $\cdot / r \cdot 1$ & حجديم نشان دادن جذب سرمايههاى & & & \\
\hline$\cdot|\Delta| \cdot \mid$ & . & $\cdot|0| \cdot$ & $\cdot / r \wedge \Lambda$ & حجيم نشان دادن سطح نظارتها & & & \\
\hline$\cdot / r \Delta q$ & . & $\cdot / \pi \Delta q$ & - / rA & جمجيم جلوه دادن ميزان يذيرش & & & \\
\hline
\end{tabular}

باتوجه به وزن نهايى هريك از مولفهها و تزارهها، مشخص مىشود، مقدار ناساز كارى زير //.

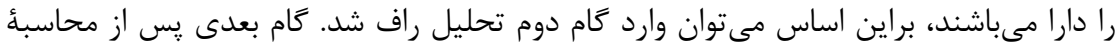

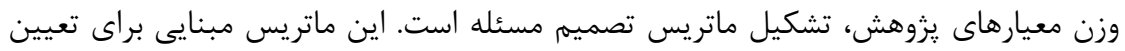

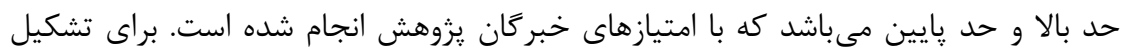


หา1 امانى بابادى، الخَى شناختى انتخاب تاثير تذار ترين راهبرد افشاى كربن براساس فشارهاى ...

ماتريس تصميم فاصلهاى، ابتدا نظر خبر كان دربارٔ وضعيت هريك از مولفهها در هريك از كزارهها

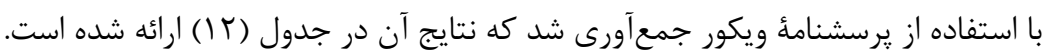

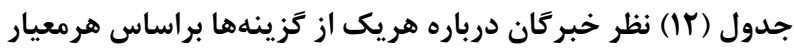

\begin{tabular}{|c|c|c|c|c|c|c|c|c|c|c|c|c|c|c|}
\hline \multicolumn{15}{|c|}{ مشار كتكننده اول } \\
\hline M14 & M13 & M12 & M11 & M10 & M9 & M8 & M7 & M6 & M5 & M4 & M3 & M2 & M1 & \\
\hline 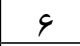 & r & 11 & $\Lambda$ & $1 T$ & r & r & 1. & $\Delta$ & $q$ & $\Delta$ & f & r & 11 & N1 \\
\hline 9 & 11 & 1. & $1 T$ & $q$ & $\Lambda$ & 14 & 11 & V & $\Lambda$ & 1. & 15 & $\Delta$ & 9 & N2 \\
\hline V & 9 & $\Delta$ & 1. & 9 & f & $\Delta$ & f & 1. & 11 & r & r & $\Lambda$ & $q$ & N3 \\
\hline \multicolumn{15}{|c|}{ مشاركت كننده دوم } \\
\hline M14 & M13 & M12 & M11 & M10 & M9 & M8 & M7 & M6 & M5 & M4 & M3 & M2 & M1 & \\
\hline 1. & 9 & IT & 1. & V & V & V & 11 & 1. & 15 & $\Lambda$ & 11 & 1. & سו & N1 \\
\hline IT & $\Lambda$ & Ir & $\Lambda$ & 1. & 11 & 1. & 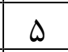 & V & 9 & 1. & f & $\Delta$ & $\Lambda$ & $\mathrm{N} 2$ \\
\hline 11 & $1 T$ & V & $\Lambda$ & 9 & IT & 1. & 14 & 9 & 9 & 1. & 11 & V & 1. & N3 \\
\hline
\end{tabular}

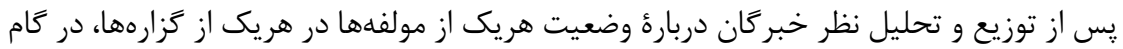

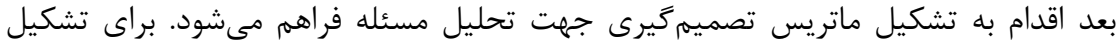

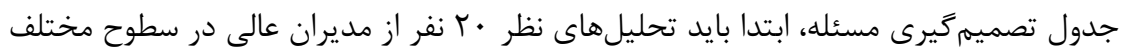

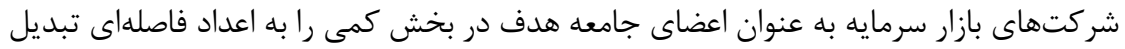

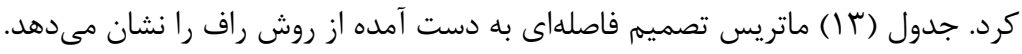

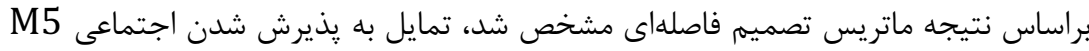

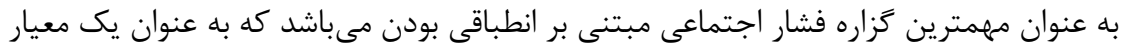

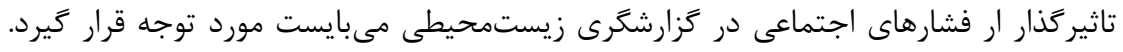

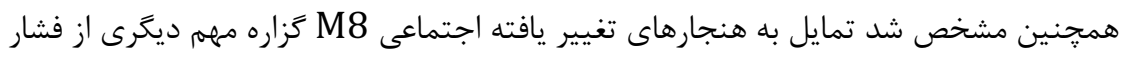
اجتماعى مبتنى بر انطباقى بودن است كه از منظر تاثيركذارى فشارهاى اجتماعى در دراعي

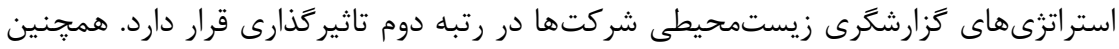

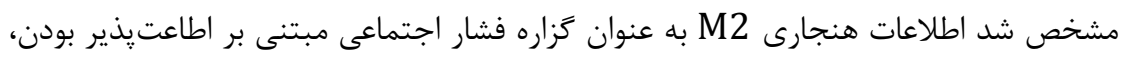

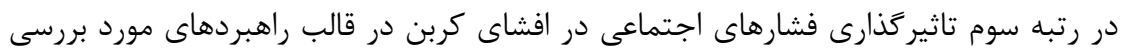

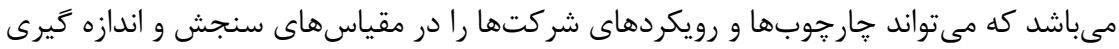

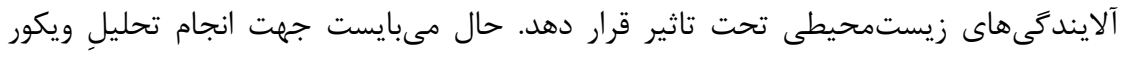
خاكسترى تزارههاى يزوهش مجددا مورد تحليل قرار كيرند. 
دو فصلنامه حسابدارى ارزشى و رفتارى، سال ينجم، شماره دهم، پِاييز و زمستان وجها

\begin{tabular}{|c|c|c|c|c|c|c|c|c|c|c|c|c|c|c|}
\hline \multicolumn{15}{|c|}{ جدول (זI) ماتريس تصميم فاصلهاى } \\
\hline \multicolumn{2}{|c|}{ M7 } & \multicolumn{2}{|c|}{ M6 } & \multicolumn{2}{|c|}{ M5 } & \multicolumn{2}{|c|}{ M4 } & \multicolumn{2}{|c|}{ M3 } & \multicolumn{2}{|c|}{ M2 } & \multicolumn{2}{|c|}{ M1 } & \\
\hline حد & حد & حد & حد & حد & حد & حد & حد & حد & حد & حد & حد & حد & حد & \\
\hline | بالا & | קايين | & بالا & קايين & بالا & يايين & بالا & | يايين & بالا & | بايين & بالا & |رايين & بالا & يايين & \\
\hline$(\mathrm{U})$ & (L) & $(\mathrm{U})$ & (L) & $(\mathrm{U})$ & (L) & $(\mathrm{U})$ & (L) & $(\mathrm{U})$ & (L) & $(\mathrm{U})$ & (L) & $(\mathrm{U})$ & (L) & \\
\hline$r \cdot / \Lambda \Lambda$ & $19 / 14$ & rI/FF & $1 N / 9$. & rv & $r f$ & $r q / 11$ & $r \& 1.4$ & $r \Lambda$ & ro & $r q / r \cdot$ & $T V / \Lambda$. & $T V / I V$ & $r \varepsilon / \| Q$ & N1 \\
\hline $19 / 1 T$ & $1 V / 90$ & $r F / \backslash Q$ & $r r / 9 q$ & ri/l. & $r q / 1 V$ & rq & TV & $r 9 / 19$ & $r V / \Delta \varphi$ & $r \cdot / F \Delta$ & TN/IV & $r \cdot / \cdot v$ & TN/DQ & $\mathrm{N} 2$ \\
\hline$r F / \cdot 1$ & Tr/AI & $19 / 91$ & IV/GT & $r \mu / \cdot r$ & $r I / / T$ & $r V / 11$ & $r \Delta / q$. & TV/QG & $r 9 / 10$ & $r \cdot / v q$ & $r N / Q 1$ & $r N / 11$ & TEIVG & N3 \\
\hline \multicolumn{2}{|c|}{ M14 } & \multicolumn{2}{|c|}{ M13 } & \multicolumn{2}{|c|}{ M12 } & \multicolumn{2}{|c|}{ M11 } & \multicolumn{2}{|c|}{ M10 } & \multicolumn{2}{|c|}{ M9 } & \multicolumn{2}{|c|}{ M8 } & \\
\hline حد & حد & حد & حد & حد & حد & حد & حد & حد & حد & حد & حد & حد & حد & \\
\hline بالا & | بايين & بالا & پايين & بالا & يايين & بالا & | يايين & بالا & | يايين & بالا & |ֶايين & بالا & پايين & \\
\hline (U) & $(\mathrm{L})$ & (U) & (L) & $(\mathrm{U})$ & $(\mathrm{L})$ & (U) & (L) & $(\mathrm{U})$ & $(\mathrm{L})$ & $(\mathrm{U})$ & (L) & $(\mathrm{U})$ & $(\mathrm{L})$ & \\
\hline $18 / \pi r$ & $1 F / 94$ & $r T / \cdot 1$ & $r \cdot / q$. & rब/ब & $1 N / \cdot 1$ & $18 / 49$ & $T F / \Delta G$ & 10 & $1 \pi$ & $r I / I r$ & $r \cdot / r$. & $r Y / \cdot T$ & $r q / \Delta q$ & N1 \\
\hline$|f| g \mid$ & $1 \% / \cdot 1$ & $r \| / /$. & $19 / 19$ & $r \mu / . q$ & $1 V / 11$ & $10 / 1$. & $r \mu / V \cdot$ & $19 / 0$. & $1 F / 49$ & $r .1 .9$ & $19 / 19$ & $r \cdot / / 4$ & rN/V9 & $\mathrm{N} 2$ \\
\hline$r / / 10$ & $19 / 1$. & $19 / 14$ & $I V / \Delta \cdot$ & $19 / 49$ & $1 F / V V$ & $19 / 11$ & $19 / \Delta \Delta$ & $10 / \mu T$ & $1 \% / v 9$ & 19/94 & $1 N / 4$. & rT/Aq & $r \cdot r \cdot$ & N3 \\
\hline \multicolumn{4}{|c|}{ رتبه سوم تاثير گذارى } & & \multicolumn{4}{|c|}{ رتبه دوم تاثير گذارى } & & \multicolumn{4}{|c|}{ رتبه اول تاثير گذارى } & \\
\hline
\end{tabular}

روش ويكورخاكسترى به عنوان مهمترين بخش تحليل راف جهت بهينهسازى معيارهاى

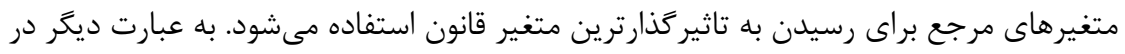

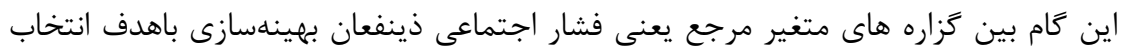

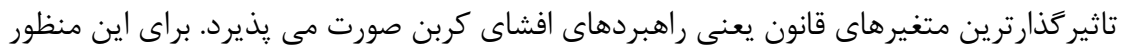

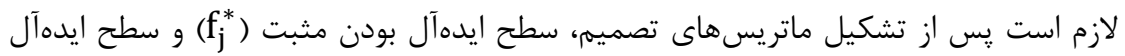

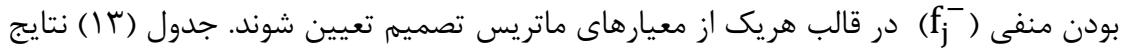
بدست آمده را نشان مى مدهد. جدول (r) تعيين ايدهآل هاى مثبت و منفى

\begin{tabular}{|c|c|c|c|c|c|c|c|c|c|c|c|c|c|c|}
\hline$\underset{A}{\vec{B}}$ & $\underset{\omega}{\mathbf{\omega}}$ & $\underset{\sim}{\Xi}$ & 占 & 肖 & 3 & $\underset{\infty}{3}$ & $\underset{v}{3}$ & హ) & ज & 3 & w & $\frac{3}{\sim}$ & 卢 & \\
\hline$\stackrel{5}{5}$ & $\frac{\dot{x}}{x}$ & $\frac{5}{?}$ & $\overbrace{0}^{\infty}$ & $\underset{>}{\stackrel{0}{<}}$ & $\frac{1}{3}$ & $\frac{1}{1}$ & $\frac{\bar{z}}{\frac{1}{y}}$ & $\stackrel{\ddot{0}}{\dot{x}}$ & $\frac{\vec{b}}{\hat{b}}$ & $\underset{1}{3}$ & $\begin{array}{l}\hat{r} \\
\hat{<}\end{array}$ & $\frac{\vec{z}}{\vec{x}}$ & $\begin{array}{l}\hat{z} \\
\hat{1}\end{array}$ & 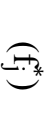 \\
\hline$\frac{1}{z}$ & $\begin{array}{l}\frac{1}{2} \\
\dot{2}\end{array}$ & $\frac{a}{r}$ & $\frac{r}{k}$ & $\frac{j}{i}$ & $\frac{\bar{c}}{\frac{n}{2}}$ & $\begin{array}{l}\dot{r} \\
\dot{<}\end{array}$ & $\frac{j}{i}$ & $\frac{\sqrt{z}}{\underbrace{}_{0}}$ & $\frac{\sigma}{0}$ & $\frac{1}{k}$ & $\frac{1}{x}$ & $\underset{<}{<}$ & $\frac{5}{2}$ & 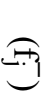 \\
\hline
\end{tabular}



امانى بابادى، الكوى شناختى انتخاب تاثير تذار ترين راهبرد افشاى كربن براساس فشارهاى ...

براساس جدول (با ) هيجِكدام از َزارهها، ايدهآل منفى بالاترى از ايدهآل مثبت ندارند و اين

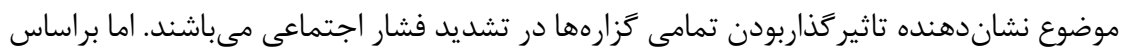
نتايج بازهم تاييد شد كه تمايل به يذيرش شدن اجن اجتماعنى

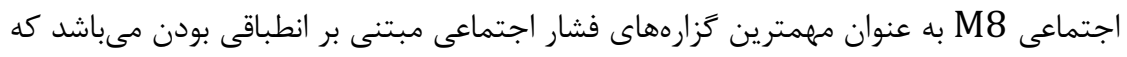

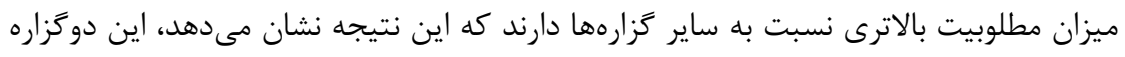

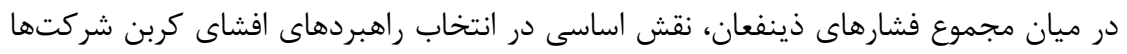

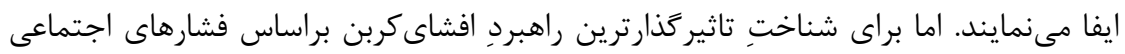

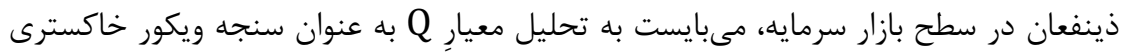

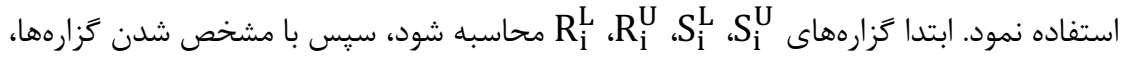

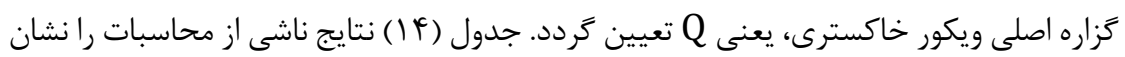
جدول (If) تحليل كزارههاى روش ويكور خاكسترى

\begin{tabular}{|c|c|c|c|c|c|c|c|}
\hline$Q_{i}^{L}$ & $\mathrm{Q}_{\mathrm{i}}^{\mathrm{U}}$ & $\mathrm{R}_{\mathrm{i}}^{\mathrm{L}}$ & $\mathrm{R}_{\mathrm{i}}^{\mathrm{U}}$ & $S_{i}^{L}$ & $\mathrm{~S}_{\mathrm{i}}^{\mathrm{U}}$ & كد & راهبردهاى افشاى \\
\hline - $|9|$ ATVTY & - /Fetgia & $\cdot / 4 q 4 \cdot q$. & - TLUVIA & T/TAIVVV & $|/ 114| \varepsilon \wedge$ & N1 & راهبرد اختيارى \\
\hline$\cdot 11 \mathrm{r} \cdot \cdot 191$ & - |qTTLIS & -/VAIVAI & $\cdot / 4 \mid r q . q$ & Y/AqIVTS & I/VVYGID & $\mathrm{N} 2$ & راهبرد نمادين افشاء \\
\hline - lqqfसrol & $. / 4 q . r q \nabla$ & - DATFYG & - /rVVVIG & T/RTIVTA & $1 / 0 \cdot 9 V T r$ & N3 & راهبرد توسعه افشاء \\
\hline $\mathrm{R}^{-}$ & $\mathrm{R}^{*}$ & $\mathrm{~S}^{-}$ & $\mathrm{S}^{*}$ & \multicolumn{3}{|c|}{ كزارهـا } & \multirow{2}{*}{ معيارهاى سنجش } \\
\hline 1 & - /DTGTAQ & r/IVTSVV & $\cdot / / \cdots r \wedge \varphi$ & & مقدار كزار & & \\
\hline
\end{tabular}

براساس معيار تحليلى Q به عنوان سنجه تحليلِ ويكور خاكسترى كه نشان دهنده

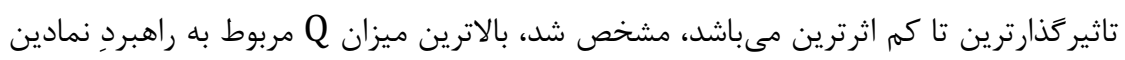

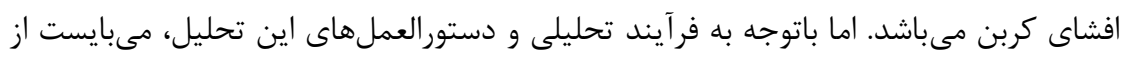

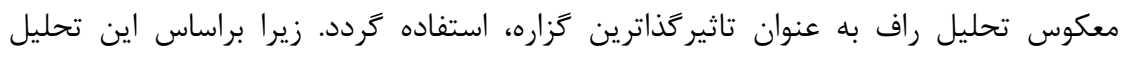

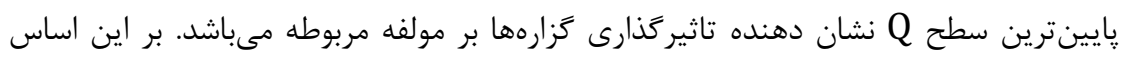

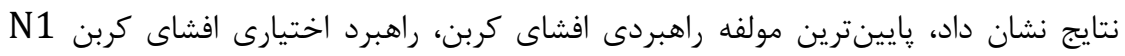

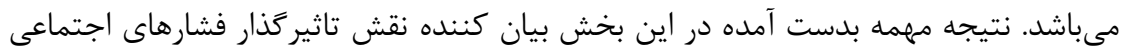

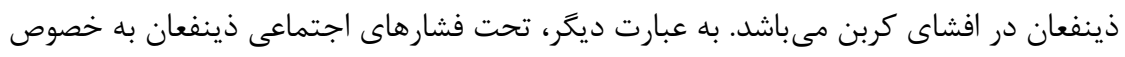


فشارهاى داراى اولويتى همجون קذيرش شدن اجتماعى و تغيير هنجارهاى اجتماعى، شركتها

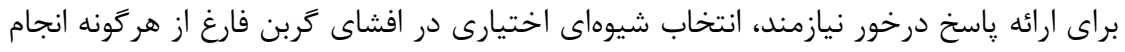

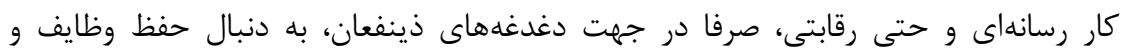

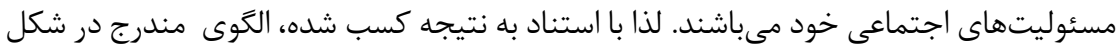

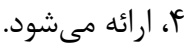

شكل (F) الكَوى تاثيركذارترين راهبرد تحت وجودِ فشارهاى اجتماعى ذينفعان

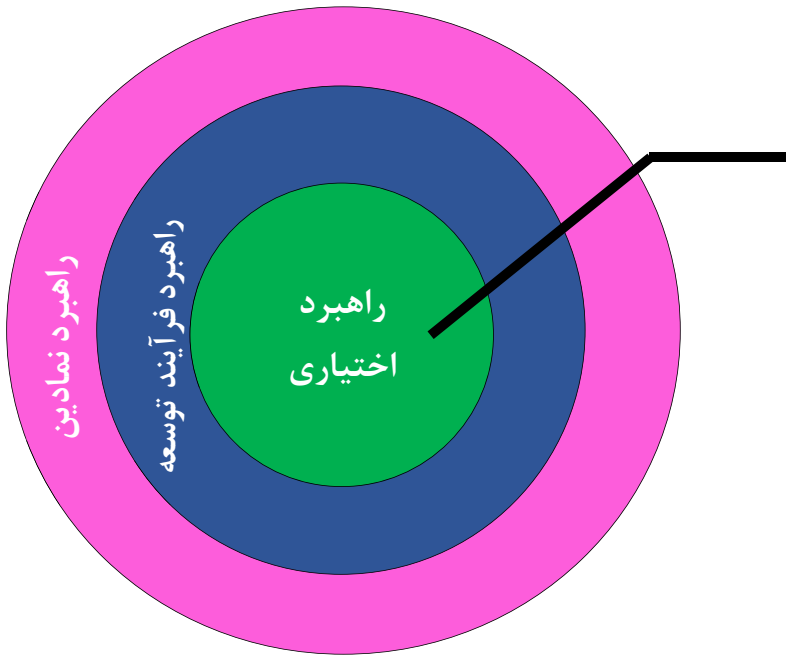

همانطور كه مشاهده مىشود، راهبرد اختيارى افشاى كربن، تحت وجود فشار اجتماعى ذينفعان،

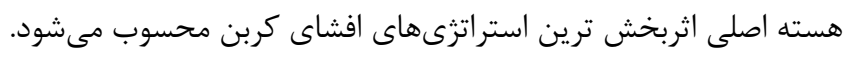

\section{9- ونتيجه كيرى و بحث}

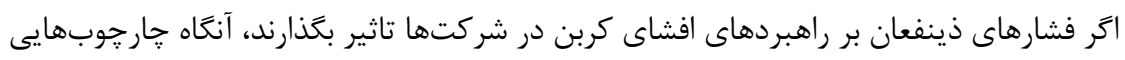

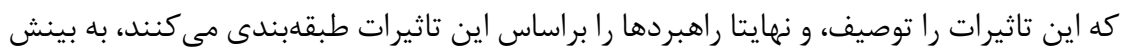

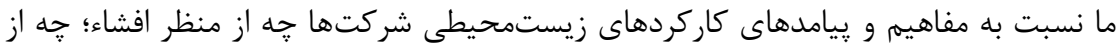

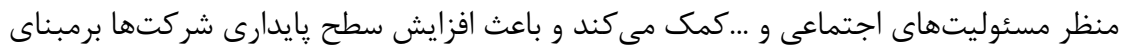

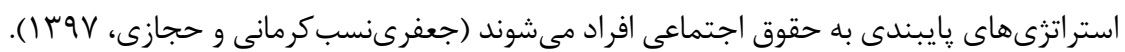
در واقع فشارهاى ذينفعان بر كاركردهاى شفافيتزا در فرآيندهاى زيستمدحيطى شركت إنها كمكى

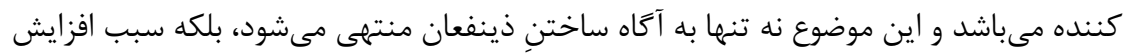

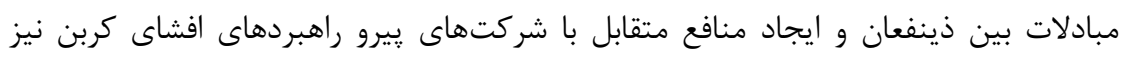
مىشود، خراكه شركتها مسئوليت متقاعدكردن مخاطبان ذينفع نسبت به مشروعيت سازمان، 
را جزء وظايف مههم اجتماعى و حتى رقابتى خود قلمداد مىنمايند. در واقع هدف اين يزوهش

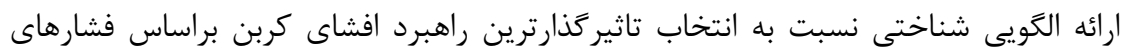

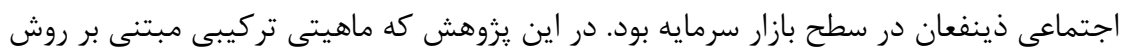

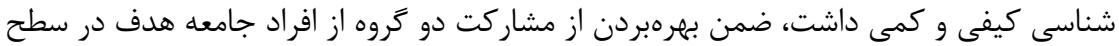

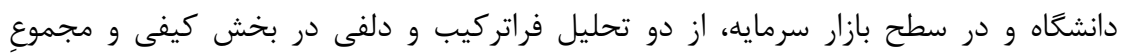

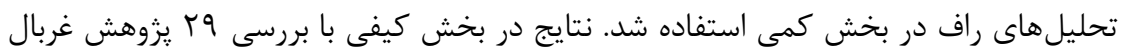

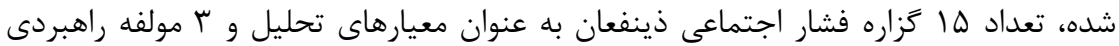

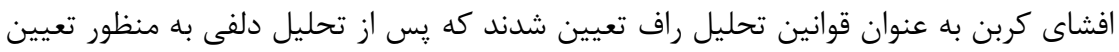

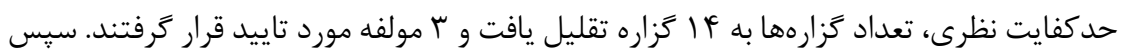
در سطح تحليل مجموعه راف كه براساس تحليلهاى ماتريسى و با مشاركت مديران در در لايههاى

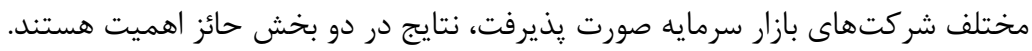

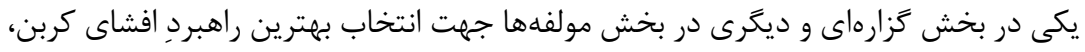

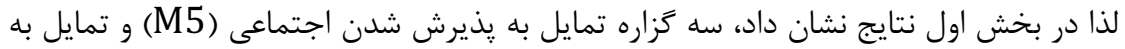

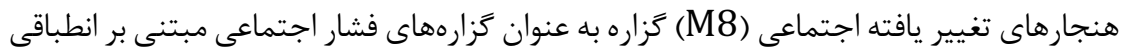

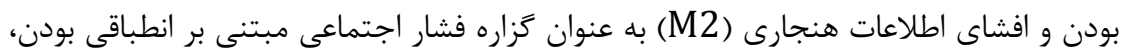
تاثير تذارى نقش را در تعيين راهبردهاى افشاى كربن در سطح شركتهاى بازار سرمايه از خود

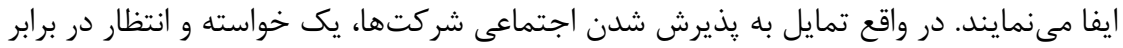

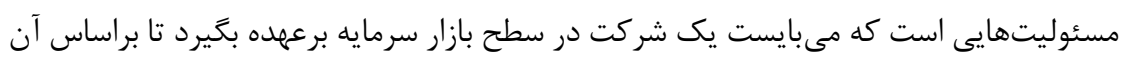

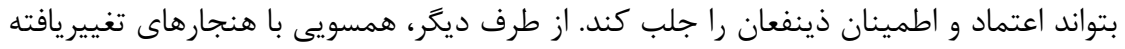

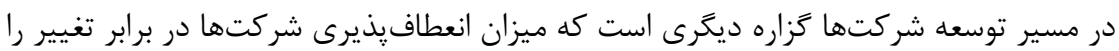

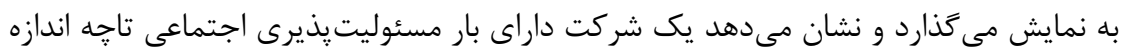

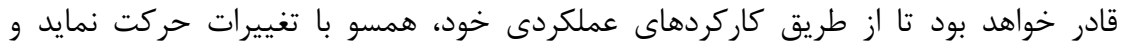

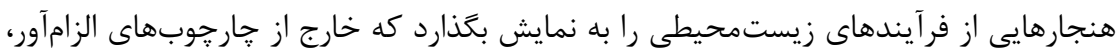

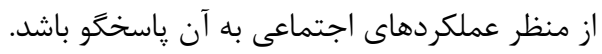

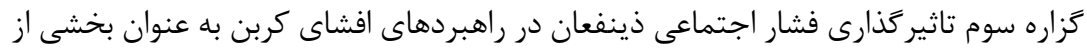

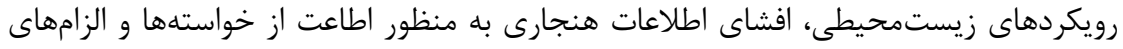

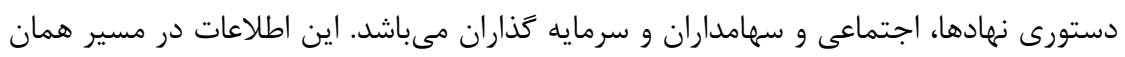

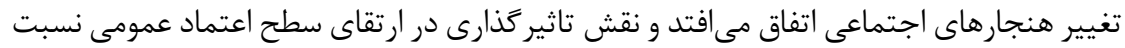

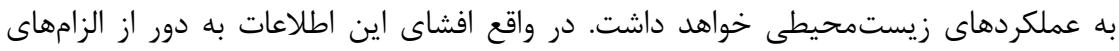

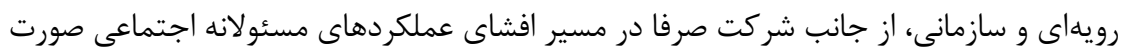


مى يذيرد. در بخش دوم مجموع تحليلهاى راف مشخص شد، راهبردِ افشاى اختيارى مهمترين

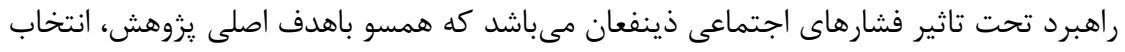

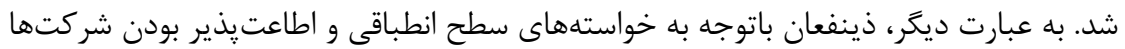

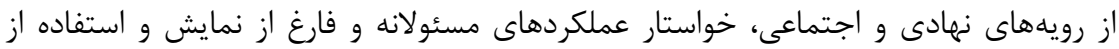

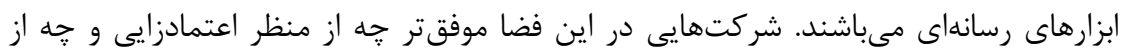

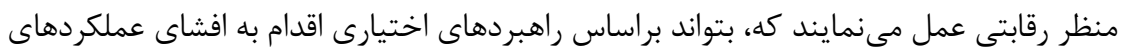

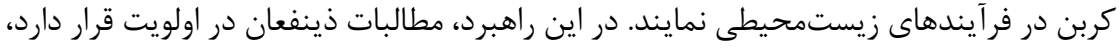

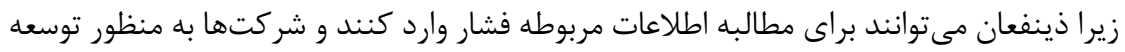

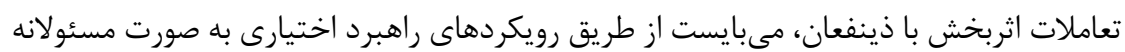

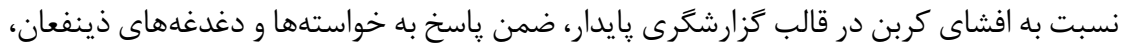

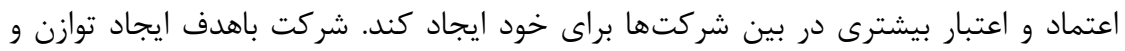

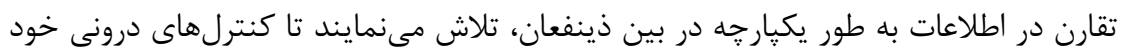
براى كاهش ضايعات ارتقاء بخشند و با توسعه ابعاد فرهنگ زيستمحيطى، سطح بايبندى بـانه

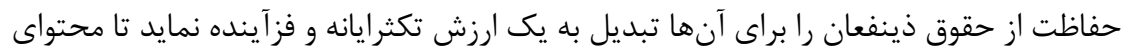

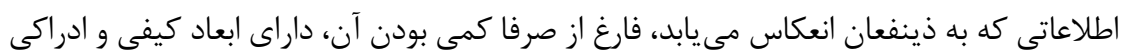

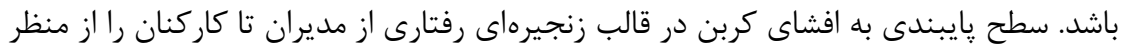

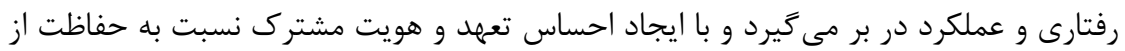

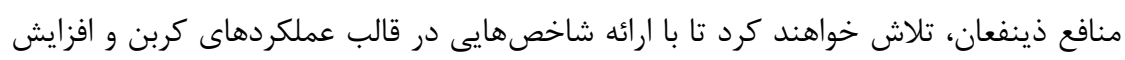

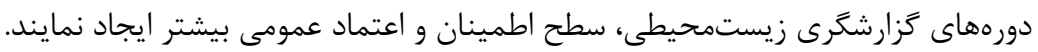

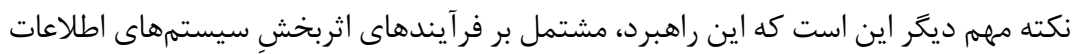

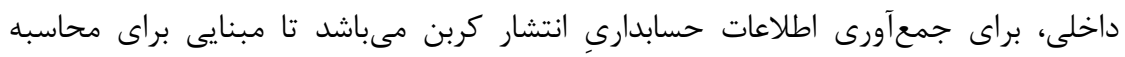

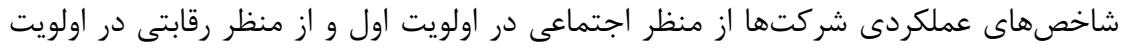

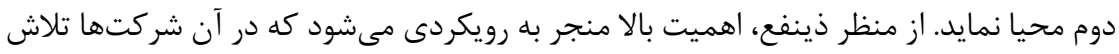

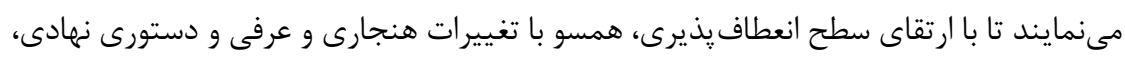

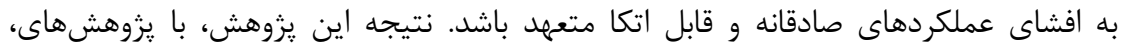

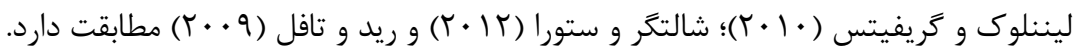

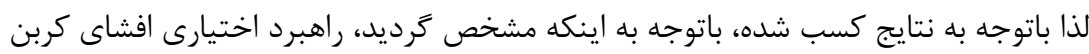

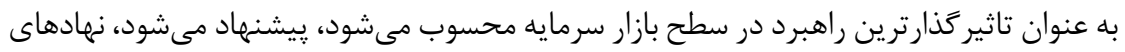

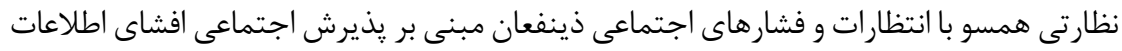

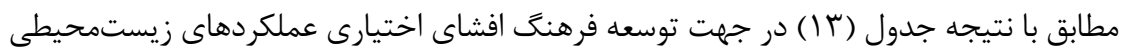


با ايجاد بسترى براى ارائه ايدهها جهت همه كير نمودن فعاليتهاى زيستمحيطى، ارزشهاى

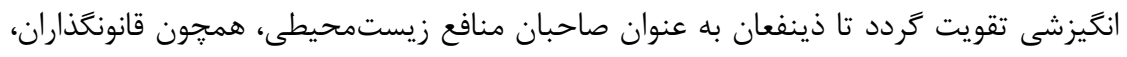

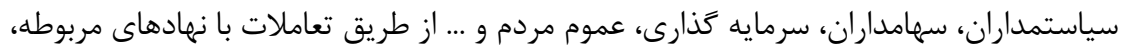

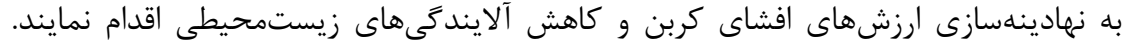

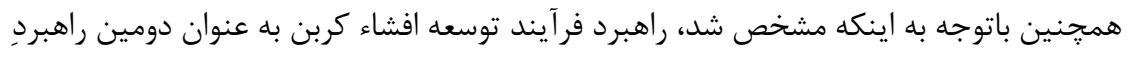

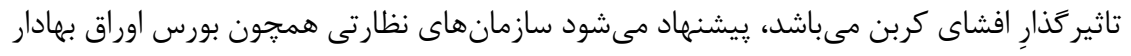

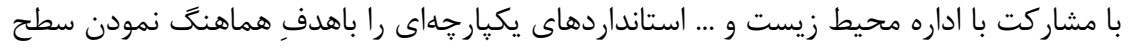

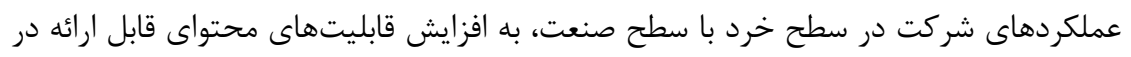

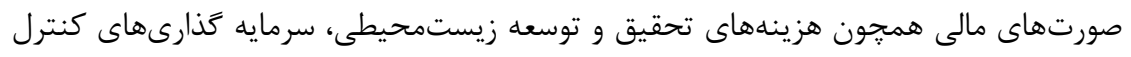

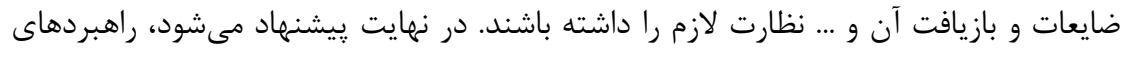

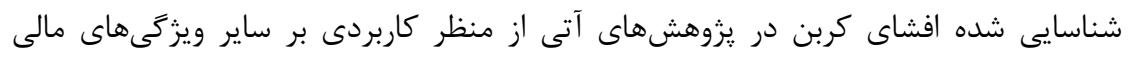

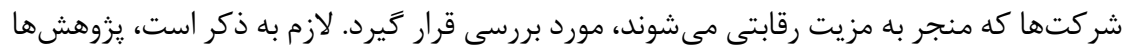

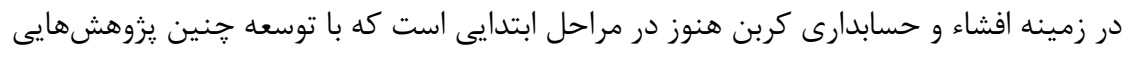

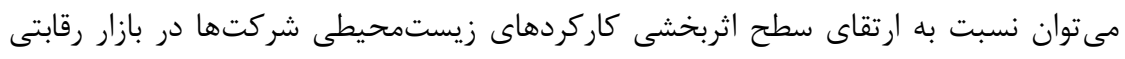
اميدوار بود.

\section{فهرست منابع}

ابطحى فروشانى، زينت السادات؛ فرصتكار، احسان؛ خوشنوايور، نادر؛ ابطحى فروشانى، سيدتقى.

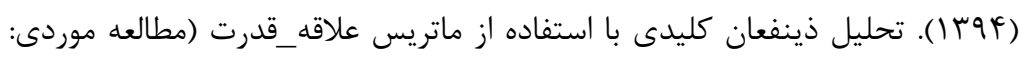

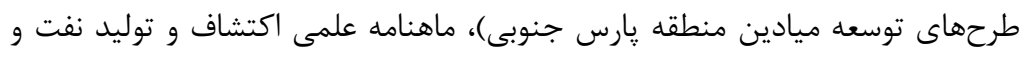

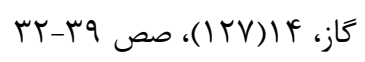

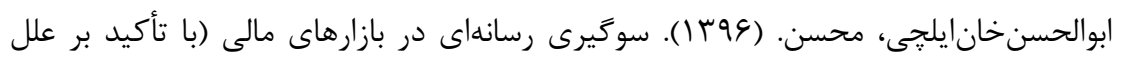

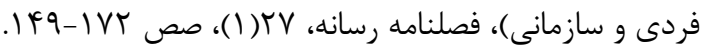

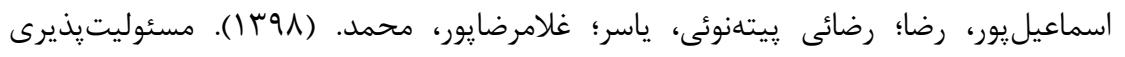

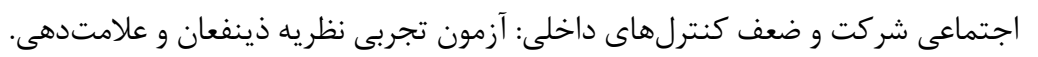

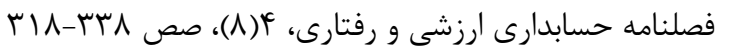

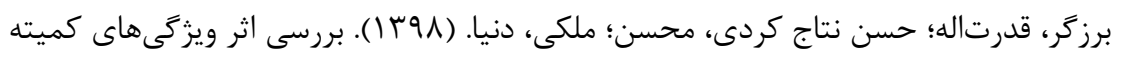

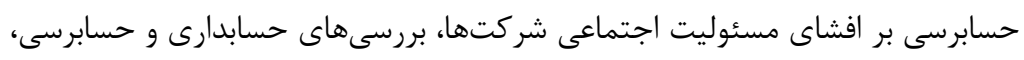

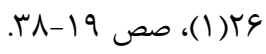


تيمورى، مهسا؛ بزازان، فاطمه؛ اندايش، يعقوب. (1 (1). شناسايى بخشهاى كليدى اقتصاد

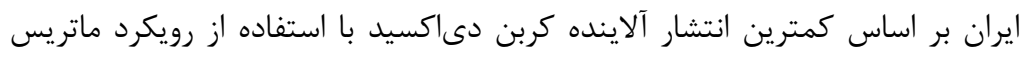

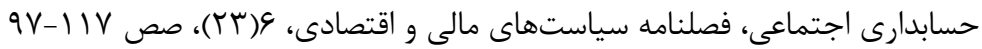

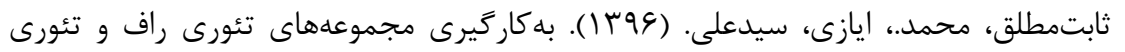

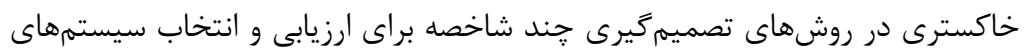

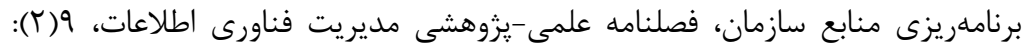
rrg-rIV

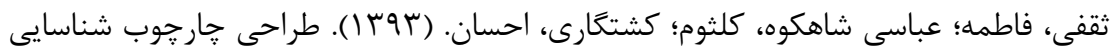

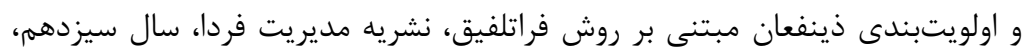

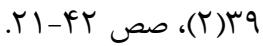

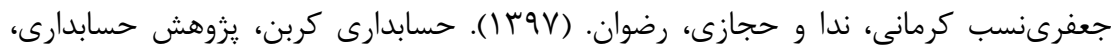

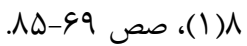

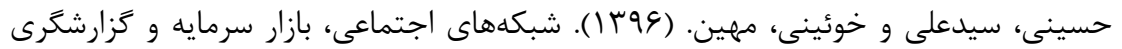

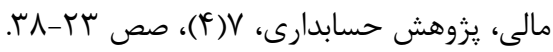

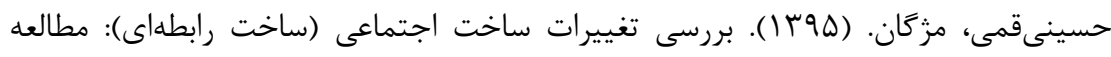

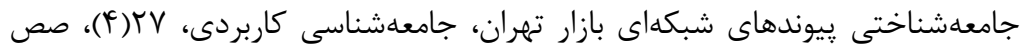

$\mid \Delta Y-I V \cdot$

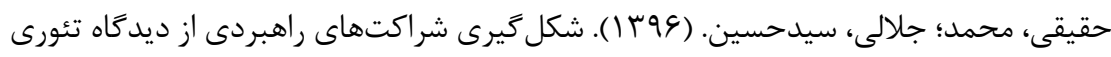

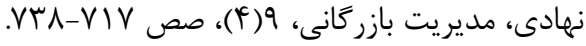

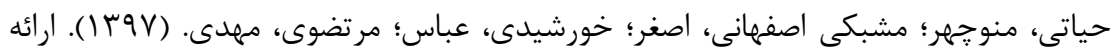

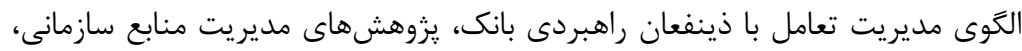
$\Delta V-V Y$ T

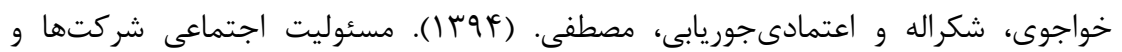

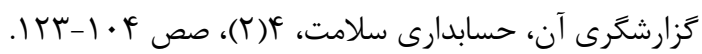

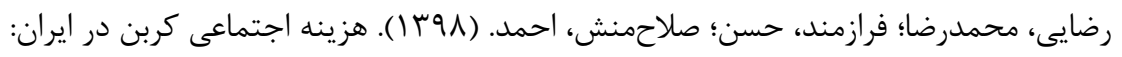

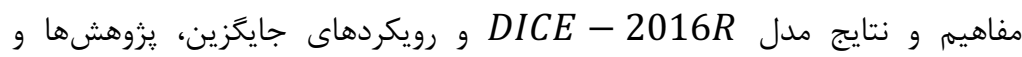

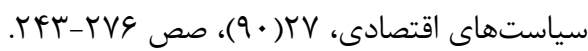

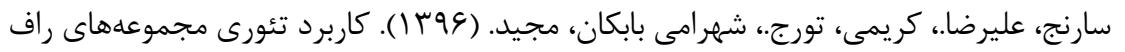
براى پيشبينى قيمت سهام (مطالعه موردى: بانك صادرات ايران)، راهبرد مديريت مالى، 


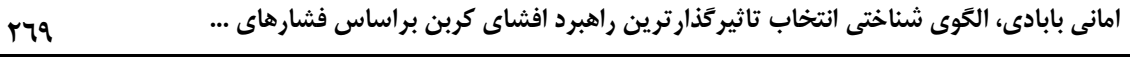

$$
\begin{aligned}
& \text { سليمانى، غلامرضا و مجبورىيزدى، هدى. (1) (1). بررسى تاثير استراتزى زيستمحيطى، عدم } \\
& \text { اطمينان زيستمحيطى و تعهد مديريت ارشد بر عملكرد زيستمحيطى شركتى: نقش }
\end{aligned}
$$

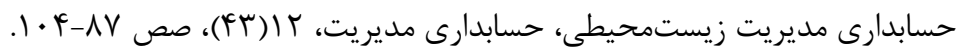

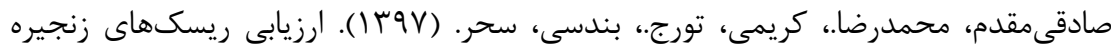

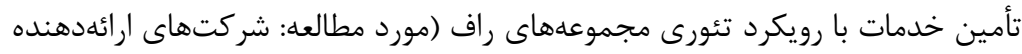

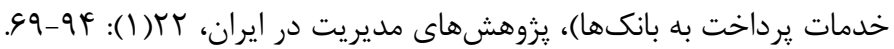

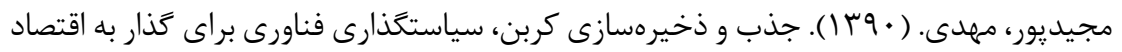

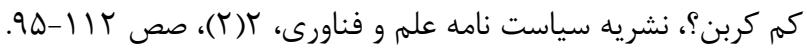

$$
\begin{aligned}
& \text { مرادى، مجيد. (لهوبا). نقش تئورى مشروعيت و تئورى ذينفعان در مسئوليت اجتماعى }
\end{aligned}
$$

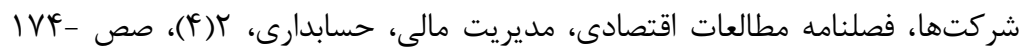

$$
\begin{aligned}
& .119
\end{aligned}
$$

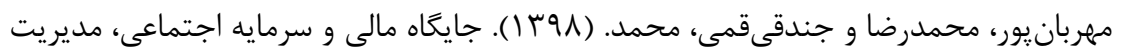

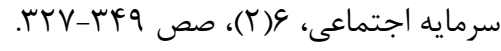

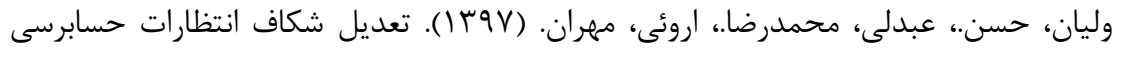

$$
\begin{aligned}
& \text { براساس استراتثىهاى منابع انسانى از طريق رويكرد تئورى راف و تئورى خاكسترى، مهرى، }
\end{aligned}
$$

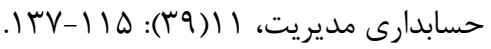

Agyei, S. K., and B. Yankey. 2019. Environmental reporting practices and performance of timber firms in Ghana: Perceptions of practitioners, Journal of Accounting in Emerging Economies, 9(2): 268-286. https://doi.org/10.1108/JAEE-12-2017-0127

Attride-Stirling, J. 2001. Thematic networks: an analytic tool for qualitative research, Commission for Health Improvement, https://doi.org/10.1177/146879410100100307

Awaysheh, A., and R. D. Klassen, 2010. The impact of supply chain structure on the use of supplier socially responsible practices. International Journal of Operations \& Production Management, 30, 1246-1268. https://doi.org/10.1108/01443571011094253

Battiston, P., and S. Gamba. 2016. The impact of social pressure on tax compliance: A field experiment, International Review of Law and Economics, 46(5): 7885. https://doi.org/10.1016/j.irle.2016.03.001

Besharov, M, L., and W. K. Smith. 2014. Multiple institutional logics in organizations: Explaining their varied nature and implications. Academy of Management Review, 39, 364-381. https://doi.org/10.5465/amr.2011.0431

Brink, A, G., F. Tang, and L. Yang. 2016. The Impact of Estimate Source and Social Pressure on Auditors' Fair Value Estimate Choices. Behavioral Research in Accounting, 2(28): 29-40. 
Chiou, Ch, L., and P. G. Shu. 2019. How does foreign pressure affect a firm's corporate social performance? Evidence from listed firms in Taiwan, Journal of Multinational Financial Management, 51(2): 1-22. https://doi.org/10.1016/j.mulfin.2019.04.006

De Villiers, C., and D. Alexander. 2014. The institutionalisation of corporate social responsibility reporting. The British Accounting Review, 46(2): 198-212. https://doi.org/10.1016/j.bar.2014.03.001

DiMaggio, P. J., and W. W. Powell. 1983. The iron cage revisited: Institutional isomorphism and collective rationality in organizational fields. American Sociological Review, 48(1): 147-160. https://doi.org/10.2307/2095101

Earnhart, D., and J. M. Leonard. 2014. Environmental Audits and Signaling: The Role of Firm Organizational Structure, Resource and Energy Economics, http://dx.doi.org/10.1016/j.reseneeco.2016.01.002

Friedland, R., and R. R. Alford. 1991. Bringing society back in: Symbols, practices and institutional contradictions. In The new institutionalism in organizantial analysis. Chicago: University of Chicago Press.

Fu, L., D. Boehe, M. Orlitxky, and D. L. Swanson. 2018. Managing stakeholder pressures: Toward a typology of corporate social performance profiles, Long Range Planning, 52(6): 101-147. https://doi.org/10.1016/j.lrp.2018.08.002

Graafland, J., and H. Smid. 2017. Reconsidering the relevance of social license pressure and government regulation for environmental performance of European SMEs, Journal of Cleaner Production, 141(10): 967-977. https://doi.org/10.1016/j.jclepro.2016.09.171

Greco, S., Matarazzo, B., and Slowinski, R. (2001). Rough sets theory for multicriteria decision analysis, European Journal of Operational Research, 129(1): 1-47

Hahn, R., D. Reimsbach, and F. Schiemann. 2015. Organizations, climate change, and transparency: Reviewing the literature on carbon disclosure, Organization and Environment, 28(3): 80-102. https://doi.org/10.1177/1086026615575542

Hassan, A. and X. Guo. 2017. The relationships between reporting format, environmental disclosure and environmental performance: An empirical study, Journal of Applied Accounting Research, 18(4): 425-444. https://doi.org/10.1108/JAAR-06-2015-0056

Herold, D. M. 2019. Has carbon disclosure become more transparent in the global logistics industry? An investigation of corporate carbon disclosure strategies between $2010 \quad$ and 2015. Logistics, 2, 13. https://doi.org/10.3390/logistics2030013

Hill, C. W., T. M. Jones. 1992. Stakeholder agency theory. Journal of Management Studies, 29(3): 131-154. https://doi.org/10.1111/j.14676486.1992.tb00657.x

Iredele, O, O. 2020. Measuring performance in corporate environmental reporting in Nigeria, Measuring Business Excellence, 24(2): 183-195. https://doi.org/10.1108/MBE-05-2019-0040

Kolk, A., D. Levy, and J. Pinkse. 2008. Corporate responses in an emerging climate regime: The institutionalization and commensuration of carbon disclosure. The European Accounting Review, 17(2): 719-745. https://doi.org/10.1080/09638180802489121 
Kraatz, M. S., and Block, E. S. 2008. Organizational implications of institutional pluralism. In R. Greenwood, C. Oliver, R. Suddaby, \& K. Sahlin (Eds.), The sage handbook of organizational institutionalism. London: Sage Publications Ltd. https://doi.org/10.4135/9781849200387.n10

Lee, K, H., and D. M. Herold. 2016. Cultural relevance in corporate sustainability management: A comparison between Korea and Japan. Asian Journal of Sustainability and Social Responsibility, 1(4): 1-21. https://doi.org/10.1186/s41180-016-0003-2

Lemma, T. T., Azmi Shabestari, M., Freedman, M., Lulseged, A., Mlilo, M. 2020. Corporate carbon risk, voluntary disclosure and debt maturity, International Journal of Accounting \& Information Management, Vol. ahead-of-print No. ahead-of-print. https://doi.org/10.1108/JJAIM-06-2019-0064

Linnenluecke, M. K., and Griffiths, A. 2010. Corporate sustainability and organizational culture. Journal of World Business, 45(3): 357-366. https://doi.org/10.1016/j.jwb.2009.08.006

Liu, G., X. Yin, W. Pengue, and E. Benetto. 2018. Donald Huisingh, Hans Schnitzer, Yutao Wang, Marco Casazza, Environmental accounting: in between raw data and information use for management practices, Journal of Cleaner Production, https://doi.org/10.1016/j.jclepro.2018.06.194

Luo, X. R., D. Wang, and J. Zhang. 2017. Whose call to answer: Institutional complexity and firms' CSR reporting. Academy of Management Journal, 60(3): 321-344. https://doi.org/10.5465/amj.2014.0847

Mata, C., A. Fialho, and T. Eugénio. 2018. A Decade of Environmental Accounting Reporting: What we know? Journal of Cleaner Production, https://doi.org/10.1016/j.jclepro.2018.07.087

Merton, R. K. (1968). Social Theory and Social Structure. New York: The Free Press.

Meyer, J. W., and B. Rowan. 1977. Institutionalized organizations: Formal structure as myth and ceremony. American Journal of Sociology, 83(10): 340-363. https://doi.org/10.1086/226550

Mitchell, R. K., B. R. Agle, and D. J. Wood. 1997. Toward a theory of stakeholder identification and salience: Defining the principle of who and what really counts. Academy of Management Review, 22(4): 853-886. https://doi.org/10.5465/amr.1997.9711022105

Moratis, L., and M, V. Egmond. 2018. Concealing social responsibility? Investigating the relationship between CSR, earnings management and the effect of industry through quantitative analysis, International Journal of Corporate Social Responsibility, 3(8): 33-58. https://doi.org/10.1186/s40991018-0030-7

Name-Correa, A., and H. Yildirim. 2019. Social pressure, transparency, and voting in committees, Journal of Economic Theory, 184(4):104-143. https://doi.org/10.1016/j.jet.2019.104943

Pawlak, Z. 2005. Rough sets and flow graphs, Rough Sets, Fuzzy Sets, Data Mining and Granular Computing, 36(41): 1-11.

Radhouane, I., M. Nekhili, H. Nagati, and G. Paché. 2020. Is voluntary external assurance relevant for the valuation of environmental reporting by firms in environmentally sensitive industries? Sustainability Accounting, 
دو فصلنامه حسابدارى ارزشى و رفتارى، سال ينجم، شماره دهم، پإييز و زمستان و9"1

\begin{tabular}{lllll}
\hline \hline $\begin{array}{l}\text { Management and Policy } \\
\text { https://doi.org/10.1108/SAMPJ-06-2018-0158 }\end{array}$ & 11(1): & 65-98.
\end{tabular}

Reid, E. M., and M, W. Toffel. 2009. Responding to public and private politics: Corporate disclosure of climate change strategies. Strategic Management Journal, 30(3): 1157-1178. https://doi.org/10.1002/smj.796

Saka, C., and T. Oshika. 2014. Disclosure effects, carbon emissions and corporate value, Sustainability Accounting, Management and Policy Journal, 5(1): 2245. https://doi.org/10.1108/SAMPJ-09-2012-0030

Schaltegger, S., and J. Hörisch. 2015. In search of the dominant rationale in sustainability management: Legitimacy or profit seeking? Journal of Business Ethics, 145(2): 1-18. https://doi.org/10.1007/s1055101528543.

Schaltegger, S., and M. Csutora. 2012. Carbon accounting for sustainability and management. Status Quo and Challenges. Journal of Cleaner Production, 36: 1-16. https://doi.org/10.1016/j.jclepro.2012.06.024

Scott, W. R. 2012. Embedding the examination of multilevel factors in an organization field context. JNCI Monographs, 20(1): 32-33. https://doi.org/10.1093/jncimonographs/lgs007

Scott, W., M, Ruef, P, Mendel, and C. Caronna. 2000. Institutional change and healthcare organizations: From professional dominance to managed care. Chicago, IL: University of Chicago Press

Shyng J, Y., G. H. Tzeng. and F. K. Wang. 2007. Rough set theory in analyzing the attributes of combination values for insurance market, Expert System with Applications, 32(1): 56-64.

Stead, J. G., W. E. Stead. 2013. Sustainable strategic management. Armonk, NY: ME Sharpe.

Theriault, J, E., L. Young, and L. Feldman Barrett. 2020. The sense of should: A biologically-based framework for modeling social pressure, Physics of Life Reviews, https://doi.org/10.1016/j.plrev.2020.01.004

Thornton, P. H., W. Ocasio, and M. Lounsbury. 2012. The institutional logics perspective: A new approach to culture, structure, and process. Oxford: Oxford University press.

Wang, P., Yuan, L., and J. Wu. 2017. The joint effects of social identity and institutional pressures on audit quality: The case of the Chinese Audit Industry, International Business Review, 26(4): 666-682. https://doi.org/10.1016/j.ibusrev.2016.12.007

Zhang, Q., Q. Xie, and G. Wang. 2016. A survey on rough set theory and its applications, CAAI Transactions on Intelligence Technology, 1(4): 323-333. https://doi.org/10.1016/j.trit.2016.11.001 